\title{
Literature $^{1}$
}

As far as I know, this [statue of Lenin in front of the Finland Station] is the only monument to a man on an armored car that exists in the world. In this respect alone, it is a symbol of a new society. The old society used to be represented by men on horseback.

-Joseph Brodsky, "A Guide to a Renamed City"

\section{Myth}

Humankind has always lived in time, but it has not always lived in history. Archaeologists and anthropologists provide countless examples of societies, "ancient" in time or "primitive" in development, where time was experienced mythically rather than historically, where only those details of life that fit into and recapitulated the master plot of a sacred tale were

$1 \quad$ Originally appeared as

"Introduction: Myth, History, Plot, Steed" in The Shape of Apocalypse in Modern Russian Fiction (Princeton: Princeton University Press, 1989), 3-61. 
worthy of remembrance. ${ }^{2}$ The British social anthropologist Bronislaw Malinowski defined myth as

...not merely a story but a reality lived. It is not of the nature of fiction, such as we read today in a novel, but it is a living reality; believed to have once happened in primaeval times, and continuing ever since to influence the world and human destinies... Myth is to the savage, what, to a fully believing Christian, is the Biblical story of the Creation, of the Fall, of the Redemption by Christ's sacrifice on the Cross. As our sacred story lives in our ritual, in our morality, as it governs our faith and controls our conduct, even so does his myth for the savage. ${ }^{3}$

The phrases most operative in this passage are "a reality lived," "believed to have happened once in primaeval times," and "continuing ever since to influence the world and human destinies." "History," on the contrary, is perceived as the very opposite of myth - the desacralization of the past, the recording of events as they actually happened, without reference to some prefiguring master plot. What characterizes the "archaic" as opposed

42. to the "modern" human being, according to Mircea Eliade, is that the former is able, through ritual, to return periodically "to the mythical time of the beginning of things" and thereby to abolish "concrete, historical time," whereas the latter, having been cut off from this Great Time through the gradual process of desacralization and secularization, must "make himself, within history." 4 To cite just one example of how ritual served (and serves) as a shield against duration and chaos, the Babylonian New Year festival (akitu) is based on the story of an underwater "carnival" king (Tiamat) who destroys the status quo, humiliates the "real" sovereign (Marduk), and casts the participants back into a pre-time of deluge and darkness; virtually at the same time, and at the dawn of the new year, order is restored, chaos is reconfigured through the act of creation, and a sacred union (hierogamy), symbolizing the rebirth of the human being and the world, is celebrated. Here the parallels with the Christian sacrament of baptism (the ritual death of the old man followed by a new birth), which in earlier times took place on Easter and New Year's Day, are obvious. ${ }^{5}$

In the venerable confrontation between history and myth the Judaeo-Christian tradition has often been seen as a turning point. Put simply, the Old Testament prophets explained the vagaries of fate and the periodic debacles of the chosen people, the "remnant of Israel" (Zephaniah 3:13),

2 One of the best-studied examples of an older, indigenous culture that has taken on the structural models of Christian apocalyptic (imported via missionaries) is the Melanesian Cargo cult. See Peter Lawrence,
Road Belong Cargo: A Study of the Cargo Movement in the Southern Madang District, New Guinea (Manchester: Manchester University Press, 1964), and Peter Worsley, The Trumpet Shall Sound: A Study of 'Cargo' Cults in
Melanasia (London: MacGibbon $\mathcal{E}$ Kee, 1957).

3 Bronislaw Malinowski, Magic, Science, and Religion (New York: Doubleday, 1954), 100.

4 Mircea Eliade, The Myth of the Eternal Return, or Cosmos 
not by relating these events to a continually recaptured great past but by re-placing them within a plot of things to come, as trials to be borne in order to make the Israelites worthy of their status and mission. "They [the prophets] insisted," writes Amos Funkenstein, "that God's immense, universal powers were manifested by the very plight of the chosen people: only God could employ the mightiest empires as 'rods of wrath' to purge Israel, while these empires were unaware of their role in the divine plan, of their objective role in history (Isaiah 10:5-7)." One can immediately see the difference between this view of time and that, say, expressed implicitly in Hesiod's myth of declining world ages (Golden, Silver, Copper, Age of Heroes, Iron) and explicitly in Plato's doctrine of reciprocating cosmic cycles (the Politicus), where panplanetary conjunctions are linked with various terrestrial adversities to make a statement about the human being's continuous rise and fall as a moral being. ${ }^{7}$ With the Judaeo-Christian tradition, humanity had "entered" history (not of course yet history in the modern, secular sense) and that history had a straightforward movement and teleological coloring. The human being had also, as we learn in Genesis, fallen from privileged status in the Garden of Eden (the Judaeo-Christian "Great Time") into profane time and an imperfect world, and there was no way back.

The figure whose interpretation of the biblical plot from a Christian standpoint was most influential for the Western Roman Catholic tradition was St. Augustine (A.D. 354-435). Through his doctrine of the three stages of salvation (the ante legem before Moses, the sub lege during and after him, and the culminating - for this world - sub gratia initiated by Christ) and through his periodization of history into Six World Ages (with the Seventh located outside of time), he consolidated the "historiosophy" of the prophets and gave it a christocentric reading that was to dominate for centuries. ${ }^{8}$ Pivotal to this reading was the conviction, expressed in The City of God, that the Christ example was unique, unrepeatable, and end-determined. As Funkenstein explains further,

It is very clear that the apocalyptic tradition does not exclude eternal return, at times even alludes to it under the influence, perhaps, of Iranian tradition. Nor indeed does the Bible exclude eternal return - it simply is outside the horizon of biblical imageries. The uniqueness of history, or at least of its central event, became thematic only in the Christian horizon. Against Origen's theory of world succession, Saint

and History, trans. William R. Trask and Literature [Oxford: Oxford (Princeton: Princeton University Press, 1954), ix. C.. in this regard Engels' remark in a letter to Ernst Bloch that "We make our history ourselves" (my emphasis; cited in Raymond Williams, Marxism
University Press, 1977], 85).

5 Eliade, Myth of Eternal Return, 55-59.

6 Amos Funkenstein, " $A$ Schedule for the End of the World: The Origins and Persistence of the Apocalyptic Mentality," in Visions of Apocalypse: End or Rebirth?, ed. Saul Friedlander et al. (New York: Holmes and Meier, 1985), 46.

7 Harald A.T. Reiche, "The Archaic Heritage: Myths of Decline 
Augustine insisted that Christ came only once for all times. The difference is rather that while the apocalyptic writer takes his proof from Scripture and history, the Greek philosopher relies on astronomical-cosmological speculations. ${ }^{9}$

So with the Judaeo-Christian model the Great Time of the past (the Garden of Eden) was cast into the future (the New Jerusalem), and the steady organ bass of apocalyptic thinking came gradually to drown out the Greek music of the spheres. ${ }^{10}$ Ironically, the figure of the circle, distinct from that of the repeating cycle, was not eliminated entirely, since the New Jerusalem not only replaced but was a return to the lost garden as a reward for trials suffered in the name of the faith, the shape of history becoming, in Karl Löwith's apt formulation, "one great detour to reach in the end the beginning." ${ }^{\prime 1}$

But what is meant precisely by the term "apocalyptic thinking" and how does it relate to the "bookish," "scribal" nature of the revealed message? There are so many apocalypses and so many non-biblical myths of the End that this is no easy question to answer. In an effort to locate certain finite transhistorical categories, such scholars of myth as Franz Cumont and

44. Eliade have been apt to cast their narratives all the way back to ancient Iranian legends about an end of the world by fire, which then, presumably, migrated westward - the ekpyrosis that occupies a central position in the religious systems of Stoicism, the Sibylline Oracles, and Judaeo-Christian literature. ${ }^{12}$ Biblical scholars, however, seem to be more restrained in their application of terminology; they draw a sharp line between "eschatology," or knowledge of the end (eskhaton), which any culture may announce it possesses, and "apocalypticism," or the "distinctive form of teaching about history and its approaching End" found in the Judaeo-Christian tradition. ${ }^{13}$ It may clarify matters, therefore, to view apocalypticism as "a species of the genus eschatology," with the implication that there is "an important difference between a general consciousness of living in the last age of history and a conviction that the last age itself is about to end, between a

and End in Antiquity," in Visions of Apocalypse: End or Rebirth?, ed. Saul Friedlander et al. (New York: Holmes and Meier, 1985), 27-29.

8 Marjorie Reeves, "The development of apocalyptic thought: medieval attitudes," in The Apocalypse in English Renaissance Thought and Literature, ed. C.A. Patrideas and Joseph Wittreich (Ithaca: Cornell University Press, 1984), 41.

9 Funkenstein, "A Schedule," 50; see also Jaroslav Pelikan, Jesus Through the Centuries
(New Haven: Yale University Press, Religions (Paris) (January-June 1985), 21-33.

10 The ancient Greek interest in astrological signs and configurations continued in the Christian tradition well into the Middle Ages and is prominent in such writers as Dante.

11 Karl Löwith, Meaning in History: The Theological Implications of the Philosophy of History (Chicago: University of Chicago Press, 1949), 183.

12 Franz Cumont, "La fin du monde selon les mages occidentaux," Revue de l'Histoire des 1931): 29-96; cited Eliade, Myth of Eternal Return, 124.

13 Bernard McGinn, "Early Apocalypticism: the ongoing debate," in The Apocalypse in English Renaissance Thought and Literature, ed. C.A. Patrides and Joseph Wittreich (Ithaca: Cornell University Press, 1984), 6. Cf. also "Apocalypticism in its Jewish origins is distinguishable from two related terms common in biblical theology and the history of religions: eschatology and prophecy. Apocalypticism is a 
belief in the reality of the Antichrist and the certainty of his proximity (or at least of the date of his coming), between viewing the events of one's own time in the light of the End of history and seeing them as the last events themselves." ${ }^{14}$ In this regard, the "wholesale invasion of Persian religious ideas into post-exilic Judaism as the determining factor in the rise of apocalypticism are now generally discounted," having been supplanted by more plausible "gradualist" theories about the interaction of Canaanite mythology and Near Eastern Wisdom traditions with indigenous Judaism (or Judaisms) as it existed in the Hellenistic world. ${ }^{15}$ Thus the "genre" of the apocalypse, according to those who have examined it most closely, is now believed to have arisen in the third and second centuries B.C. under the impulse of a Jewish nationalism, which was itself a natural outgrowth of, rather than a radical departure from, the "proto-apocalyptic" phases associated with the Canaanite and Wisdom antecedents.

The Revelation of John, or the Apocalypse, as it is known by its Greek name, is only one of a number of extant apocalyptic texts, some from the Intertestamental period and entirely Jewish in origin (I Enoch, Daniel), others from Christianity's first century (the synoptic Gospels, I and II Thessalonians), and others still from the later Patristic tradition (Shepherd of Hermas, Testament of the Lord, Apocalypse of Peter, Vision of Paul). Still, the Apocalypse of John, which is now generally thought to have been written c. 90-95 A.D., has become the most famous (or notorious) of all apocalypses, the one most laymen have in mind when they speak of the Apocalypse. And it in turn has become the text that has most palpably influenced our Western views of history as a plot with: (1) a beginning by divine fat (the creation), (2) a tale of early catastrophe (the fall of Adam and Eve), (3) a later privileged moment of crisis (the incarnation, crucifixion, and resurrection), and (4) a final crescendo with awesome dénouement (the Parousia, or Second Coming, of Christ, followed by the replacement of the old world by a "new heaven and new earth"). ${ }^{16}$ Narratologically speaking, the Apocalypse, which both comes at the end of the Bible and tells of the

species of the genus eschatology, that it, it is a particular kind of belief about the last things - the End of history and what lies beyond it. Scriptural scholars have used the term apocalyptic eschatology to distinguish the special teachings of the prophets. (Apocalyptic eschatology may be seen as equivalent to the frequently used term Apocalyptic, formed in imitation of the German Apocalyptik.) Valuable as the distinction may be in the realm of biblical studies, the picture will obviously become blurred in later
Christian history when elements of both forms of eschatology will frequently be mingled" (Bernard McGinn, Visions of the End: Apocalyptic Traditions in the Middle Ages [New York: Columbia University Press, 1979], 3-4).

\footnotetext{
14 McGinn, Visions of the End, 3-4.

15 McGinn, "Early

Apocalypticism,” 14.

16 M.H. Abrams, "Apocalypse: theme and variations," The Apocalypse in English Renaissance Thought and Literature, ed. C.A. Patridea and Joseph Wittreich (Ithaca: Cornell University Press, 1984), 343-44.
} 
end of human history, allows that history to have a coherent and meaningful beginning and middle because it provides a fitting conclusion. ${ }^{17}$ Hence, while some scholars still argue that apocalypticism as a balance of myth, method, and way of life existed only for about two hundred years (or until the early Christians grew tired of "standing on tiptoes" 18 in the shadow of disconfirmation), most will agree with Funkenstein that "the fascination with historical time and its structure was the most important contribution of the apocalyptic mentality to the Western sense of history." ${ }^{19}$ Precisely how the Johannine conclusion, with its elaborate figures and haunting codes, dovetails with the real events of contemporary history has been a source of endless debate, and no less endless carnage, from the beginning. It has left its signature on page after page of Christian history, constituting the vast "underthought" of orthodoxy and millenarian heterodoxy (Manichaean, Messalian, Paulician, Bogomilian, Patarian, Albigensian) alike. ${ }^{20}$

What do all apocalypses have in common, how are we able to speak of them as a distinct genre? A 1979 volume of Semeia answers the question in the following way: "Apocalypse" is a genre of revelatory literature with a narrative framework, in which a revelation is mediated by an otherworldly 46. being to a human recipient, disclosing a transcendent reality which is both temporal, insofar as it envisages eschatological salvation, and spatial, insofar as it involves another, supernatural world." ${ }^{21}$ In the broadest terms, a member of the elect is deeply troubled by the affairs of his church in this world. It may be the pseudonymous Daniel, one of the maskilim or wise teachers, who must try to make sense of the persecution of the Jews under the Hellenizing program of Antiochus IV Epiphanes (167164 B.C.), a kind of "proto-Antichrist";22 or it may be John, sent into exile on the island of Patmos by the Emperor Domitian (A.D. 81-96), who must try to find justification for similar persecution of the early Christians by Rome. The seer is allowed to understand through an apocalypse, a "disclosing" or "uncovering," which translates into a series of visions of the glorious End. Hence the various magnificent figures, such as the four beasts of Daniel 7 or the beast rising out of the sea of Revelation 13, have ex eventu referents in history (i.e., the Babylonians, Medes, Persians, Greeks, Romans), but at the same time are colorful, compelling, and abstract enough to provide ready-made source material for subsequent "seers." The Whore of Babylon could be the Roman Empire in one epoch and the Church of Rome in another; the beast could be Nero redivivus in one context and a concupiscent pope, later called an "Antichrist," 23 in another.

17 Frank Kermode, The Sense of an Ending: Studies in the Theory of Fiction (New York: Oxford University Press, 1967), 5-8.

18 Pelikan, Jesus, 24.

19 Funkenstein, "A Schedule," 49, 57.
20 Frank E. and Fritzie P. Manuel, Utopian Thought in the Western World (Cambridge: Harvard University Press, 1979), 48.

21 John J. Collins, "Introduction: Towards the Morphology of a Genre," Semeia 14 (1979): 9.
22 McGinn, "Early Apocalypticism," 8.

23 In the New Testament the name "Antichrist" does not appear in Revelation, but only in I and II John. 
What is significant is that the tribulations of the profane present, of human beings in history, are rendered understandable and therefore bearable by reference to a suprahistorical intelligence (God) who, standing beyond the Beginning and the End, sends His messenger (the angel of Revelation 1:1) to one of His faithful (the "servant John") with a divine preview of history's "Finis" - that spatial metaphor for a non-temporal paradise called the New Jerusalem. Just as Christ's life culminated in a triadic pattern of trialcrucifixion-resurrection, so now does the life of humanity, that is, universal history, promise to culminate in a similar pattern (thus the Second Coming of Christ) of present crisis-coming judgment-final vindication. ${ }^{24}$

As the Semeia volume shows, the genre of apocalypse has numerous permutations: it may contain a review of universal history up to the present moment of crisis or it may involve a purely personal eschatology; the revelation itself may be presented in the form of a vision or a speech or a dialogue; the seer may go on an otherworldly journey (a Judaeo-Christian version of the utopian topos) ${ }^{25}$ or may be visited in his or her realm, etc. Yet whatever the particular variations, certain basic elements, what might be termed the epistemological "deep structure" of apocalypse, hold frm: (1) history is a unity or totality determined by God but at the same time so configured as to allow humanity, or more precisely, a member of the elect, to choose between Christ and Antichrist, between the truth coming from beyond and the mirage of worldly power, well-being, etc. that passes for truth in the here and now; (2) the moment of decision has arrived and the initial stage in the climactic pattern of crisis-judgmentvindication has begun; and (3) this coming End is viewed as tragic and retributive for those who have chosen not to uphold the faith and as triumphant for those who have. ${ }^{26}$ Above all, the apocalypticist mentality and its scribal expression in the genre of apocalypse imply the interplay

\section{McGinn, "Early} Apocalypticism,” 9 .

25 It is of course moot to argue which impulse came first the apocalyptic or the utopian. After all, Plato's presentation of his ideal republic, which Thomas More used as an important point of departure in his text, antedates the appearance of Christian apocalyptic. The foremost American scholars of utopia, Frank and Fritzie Manuel, isolate and historicize the utopian urge in the following way:

"Utopia is a hybrid plant, born of the crossing of a paradisaical, otherworldly belief of JudeoChristian religion with the Hellenic myth of an ideal city on earth. The naming took place in an enclave of sixteenth-century scholars excited about the prospect of a Hellenized Christianity. While we may loosely refer to ancient and medieval works with some utopian content as utopias, the Western utopia is for us a creation of the world of the Renaissance and the Reformation... But the relation of the utopian to the heavenly always remains problematic. Utopia may be conceived as a prologue or foretaste of the absolute perfection still to be experienced; it then resembles the Days of the Messiah or the Reign of Christ on earth of traditional Judaism and Christianity, with the vital addition of human volition as an ingredient in the attainment of that wished-for state. Or the utopia, though originally implanted in a belief in the reality of a transcendental state, can break away from its source and attempt to survive wholly on its own creative self-assurance. Whether the persistence of the heavenly vision in a secularized world, if only in some disguised shape, is a necessary condition for the duration of utopia is one of the unresolved questions of Western culture" (Manuel and Manuel, Utopian Thought, 15-17).

26 McGinn, "Early Apocalypticism," 4-6, 10-12. 
of spatio-temporal oppositions and of one's place within them: old/ new, here/there, determinism from beyond/free choice from within, the historically mired Whore of Babylon/the ahistorical New Jerusalem, etc. The perceived resolution of all opposition comes, logically enough, at the climax of the Book of Revelation. The Beast, the symbol of benighted power in this world, brings about the destruction of the Whore of Babylon (originally Rome), "the great harlot... with whom the kings of the earth have committed fornication" (Revelation 17:1-2). Against this sense of tumultuous discord is presented the marriage of the Lamb and the Bride, Christ and the "holy city... coming down out of the heaven from God" (Revelation 21:10). In effect, the final vision of the Christian hierogamy has achieved a kind of narrative optical illusion - a view of the "outside" of history from the "inside," a projection of an all-encompassing and allresolving "then" from the vantage of a beleaguered "now."

The record of how, time and again, the apocalypticist urge provoked historical confrontation in the West is immense, and can only be touched on in these preliminaries. Suffice it to say that of all the individuals who attempted to transpose the principal figures and codes of the Johannine text to the 48. terms of contemporary reality, two were pivotal to the course of Western apocalypticism - St. Augustine and Joachim of Fiore (1145-1202). In his classic The Pursuit of the Millennium, Norman Cohn has written a social history of the volatile fit between the apocalyptic plot and its numerous adaptations among sectarian movements of Northern and Central Europe during the Middle Ages. Whatever the sects (Tafurs, Flagellants, Taborites) and whatever the social basis for their unrest (religious fervor during the Crusades, fear of the Black Death, deteriorating economic conditions in feudal Europe), the pattern was uniform: these were the saving remnant whose role it was to usher in the End and inherit a renovated kingdom. In this context, the Bishop of Hippo's earlier declaration that the millennium, that is, the thousand-year period of Revelation 20:1-6 during which Satan would be temporarily bound and the martyrs would reign with Christ over the world, ${ }^{27}$ was coterminous with the reign of the church did little to dissuade what was often a rag-tag band of wanderers, itself socially disenfranchised, that saw that church as a haven of simony, voluptuousness, and the spirit of Antichrist. Officially, then, this move to legitimize the historical church as the only "City of God" on earth had enormous ramifications, not the least of which was to defuse the urgent need to look for a future Golden Age, since apparently it was

27 "In a strict sense, millenarianism, or chiliasm, was originally limited to a prophetic conviction, derived from a commentary on the fourth verse of the twentieth chapter of the Apocalypse of John, to the effect that
Christ would reign for a thousand years on earth. The pivotal events of the transition to the days of the millennium were depicted in 1 well-worn images of catastrophe: During a time of troubles empires crumble, there are titanic struggles of opposing armies, vast areas of the world are devastated, nature is upheaved, rivers flow with blood. On the morrow, good triumphs over evil, God over Satan, Christ over Antichrist. As existential experience the millennium of 
already here. As we discover in City of God (xviii: 52-53), it is not our place to tease out a divine fretwork of apocalyptic signs from the welter of current affairs: these prophecies are, in R.A. Markus' summation of the Augustinian position, "not to be read as referring to any particular historical catastrophe, but to the final winding up of all history; and the time of that no man can know." 28

But in the popular, sectarian consciousness, which could not help from noticing the disparity between the historical and ideal churches, the millenarian impulse remained strong. This is especially true after Joachim, a seminal mystic of the Catholic Middle Ages, reversed Augustinian doctrine and gave the people back their millenarianism with his triadic periodization of history: "Joachim's originality lay in his affirmation that the threefold pattern of history was as yet incomplete and that the work of the Holy Spirit, the Third Person, must shortly be made manifest in a further stage of spiritual illumination. Recasting the traditional Pauline pattern he expanded his famous doctrine of the three status in history: the first, beginning with Adam and ending with the Incarnation, has been characterized by the work of the Father; the second, beginning back in the Old Testament (to overlap with the first) and continuing until Joachim's own day, belonged to the Son; the third, with a double origin

49. Chapter 2 in the Old Dispensation and the New and about to come to fruition in the near future, would see the full work of the Holy Spirit completed. Here was a magnificent programme of progress which offered an advance still to come within history. Its novelty is well illustrated by the fact that Joachim departs decisively from the Augustinian tradition by placing the Sabbath Age of the World and the opening of the Seventh Seal of the Church clearly within history and identifying them with the third status."29

The thirteenth century, as Russia fell under the Mongol Yoke to the East, was a time of great eschatological fervor and anxiety in Europe. 1260 was, in the popular imagination, the year in which Joachim's prophecies were to come true, and the Franciscan Spirituals, whose apocalyptic hopes and fears are presented in Umberto Eco's novel The Name of the Rose, were to be the original inheritors of the third status. But as routinely happens in these matters, disconfirmation makes it possible for later generations to recalculate and retranslate the numbers and signs into their own "chosen" status. Thus Joachim's placement of this third age of the Holy Spirit within history was enormously influential for the development of

early Christianity is the counterpart of the Days of the Messiah in much of Jewish apocalyptic. The bout of violence reaches a grand climax, and then and only then is there peace-primitive priapic scenes are the inescapable anal- ogy" (Manuel and Manuel, Utopian Thought, 46-47).

28 R.A. Markus, Saeculum: History and Society in the Theology of St. Augustine (Cambridge: Cambridge University Press, 1970), 152-54.
29 My emphasis; Reeves, "Medieval Attitudes," 49-50; see also Marjorie Reeves, The Influence of Prophecy in the Later Middle Ages (Oxford: Oxford University Press, 1969). 
apocalyptic thought in the West. It surfaces, mutatis mutandis, in the programs of Müntzer, Campanella, Lessing, in the Third State of Auguste Comte, in Marx's Higher Stage of Communism, in Teilhard's Noösphere, as well as in countless nationalisms, from Savonarola's Florence to Hitler's Third Reich.30 Even Columbus' discovery of a new world in 1492 (the year the old world was scheduled to end in Russia) is largely a product of this tradition. ${ }^{31}$ And in the Russian context it can be seen in modern guise in the tripartite periodization of history advanced by such thinkers as Vladimir Solovyov and Dmitry Merezhkovsky.

\section{History}

It is difficult to imagine two students of Russian cultural history more unalike than the émigré philosopher Nikolai Berdyaev and the Soviet structuralist and semiotician Yury Lotman. Yet on one issue they are both in unequivocal agreement - the relentlessly eschatological shape of those cultural models (of history, of life, and of the two as presented

50. in literature) that have been the focus of Russia's popular and literary imagination for centuries. Berdyaev - who was powerfully influenced by Dostoevsky and who came to maturity on the eve of the revolution, when the thought systems of various Christian mystics and Marxists were brought to a boil by the expectation of a new millennium - could still claim as late as 1946 that "Russians are either apocalypticists or nihilists. Russia is an apocalyptic revolt against antiquity... This means that the Russian people, according to their metaphysical nature and calling in the world, are a people of the end [narod kontsa]."32 Lotman who came to prominence in the 1960 s as the leader of the Tartu School of structural poetics and who wrote a series of pioneering works on the thesis that art does not passively "reflect" life but actually provides models and norms that social life then tries to imitate and incorporate argued that "The historical fate of Western thought... developed in such a way that, beginning with the Middle Ages and continuing up to recent times, the idea of progress occupied a dominant position in both scientific and social thinking, coloring the whole of culture for entire historical periods. On the other hand, in the history of Russian social thought there dominated, over the course of entire historical periods, concepts of an eschatological or maximalist type." ${ }^{33}$ Whether both of these writers,

30 Manuel and Manuel, Utopian Thought, 33, 63.

31 Reeves, "Medieval Attitudes," 62 กf.

32 Nikolai Berdiaev, Russkaia ideia, (Paris: YMCA, 1946), 195.
33 Iu.M. Lotman and B.A. Uspenskii, "Spory o iazyke v nachale XIX v. kak fakt russkoi kul'tury," Trudy po russkoi i slavianskoi filologii 24 (1975): 173. 
the one more "intuitive" and given to broad, unqualified generalization and the other more "contextualist" and given to a meticulous sifting of evidence, are "objectively" correct is ultimately beside the point, since they are continuing a dialogue about the received notions of Russia's past, present, and future that is central to any discussion of their country's historical identity.

The binary oppositions by which Russians have tended to define themselves from their first steps into literacy have had, according to Lotman and Boris Uspensky, a profound impact on the eschatological view of national history passed down through the centuries. In the Roman Catholic West earthly life was from very early on "conceived of as admitting three types of behavior [on the model of heaven-purgatory-hell]: the unconditionally sinful, the unconditionally holy, and the neutral, which permits eternal salvation after some sort of purgative trial. In the real life of the medieval West a wide area of neutral behavior thus became possible, as did neutral societal institutions, which were neither 'holy' nor 'sinful', neither 'prostate' nor 'anti-state,' neither good nor bad." 34 In Russia, however, "duality and the absence of a neutral axiological sphere led to a conception of the new not as a continuation, but as a total eschatological change."35 of these oppositions, argue Lotman and Uspensky, none are more important than the fundamental temporal distinction between "old" and "new" and the fundamental spatial distinction between "east" and "west." These terms shift valence as times and audiences change. More central to our discussion, the very distinctions between space and time can overlap and interpenetrate, suggesting that in point of fact they are extensions of each other. ${ }^{36}$

This means that to a structuralist like Lotman what is determinative in Russian cultural history is the ongoing clash between "outsiders" and "insiders," between those of a "now" versus those of a "then" temporality. Indeed, a number of historians have analyzed the major turning points of Russian history - the Christianization of Rus' in 988, the period of the Mongol Yoke (1240-1480), the origins of the formula "Moscow the Third Rome" and the growth of religious nationalism in the late fifteenth and early sixteenth centuries, the Great Schism led by the Old Believers in the 1660s, and the

34 Iu.M. Lotman and B.A. Uspenskii, "Binary Models in the Dynamics of Russian Culture (to the End of the Eighteenth Century)," The Semiotics of Russian Cultural History, ed. Alexander D. Nakhimovsky and Alice Stone Nakhimovsky (Ithaca: Cornell University Press, 1985), 32.

35 My emphasis; ibid. Again, a Western observer, or "outsider," may wish to question the existence of a now almost mythical past of a "neutral axiological sphere" among medieval Catholics, especially if one considers the widespread appeal of the proto-revolutionary, millenarian heterodoxies - which decidedly did not admit any middle ground in questions of judgment and faith - studied by Cohn, but if by this the authors mean that, as a result of the
Renaissance, Reformation, and Enlightenment, the notions of "progress" and a human-centered view of the world associated with the rise of a middle class came gradually to dominate - but never to eliminate entirely - the "either/ or" mentality of apocalypticism in the West, then their formulation appears more defensible.

36 See pp. 37-38 above. 
Petrine reforms in the first quarter of the eighteenth century - in precisely these terms. ${ }^{37}$ The cast of "outsiders" (Byzantium, Turko-Mongol Empire, Western Europe) may change and what is "traditional" or "iconoclastic" may fuctuate depending on the point of view of the speaker/participant, but Lotman and Uspensky's point is well-taken: Russia has tended to define itself by radically breaking, or at least by seeing itself as radically breaking, with an earlier period. This break is never, to be sure, as clean and final as the principals might imagine for the very reason that the earlier period which is supposedly overcome is preserved willy-nilly in the cultural memory as a necessary opposition. After 988 , paganism was not forgotten but remembered because its gods became the devils of the "Christian" world (Volos/Veles $\rightarrow$ volosatik or "wood goblin") or because their previous function was preempted by a Christian counterpart (Volos/Veles $\rightarrow$ St. Blaise [Vlasy], St. Nicholas, St. George). ${ }^{38}$ Whereas Hilarion, in his celebrated "Sermon on Law and Grace" (c. 1037-1050), likens the "new" faith of the Russians to the enfranchised bride Sarah and thus to NewTestament grace but the "old" faith of Byzantium to the handmaiden Hagar and thus to Old Testament law, the archpriest Avvakum will, in another era, resort to a diametrically opposed system of contrasts. To the leader of the Old Believers, as we shall see shortly, the Nikonian reforms of the 1660 s were a betrayal of sacred tradition; what was "unorthodox," including the three-figured sign of the cross, was a fall from a better past into the "now" of the Antichrist.

But to return to our topic, Russian history has been subject not only to the distant thunder of eschatology, which views any present saeculum in light of the eskhaton, but also to the specific tremors and oscillations of apocalypticism, which, like a kind of divine seismograph, shows history's explosive conclusion to be near and predictable as soon as the shape of current events are keyed to certain texts of Judaeo-Christian tradition. As suggested earlier, "eschatological” can imply any radical break with the past, while "apocalyptic" implies the salient features of Judaeo-Christian historiosophy: history is determined by God the author, the plot is now coming to a close in the rhythm of crisis-judgmentvindication, the figures of the Johannine and other apocalyptic texts have begun to appear to the "seers" of contemporary history, etc. Here the same opposition of old/new applies, but now it is given a narrower interpretation. In general, "eschatologists” may be dour or eupeptic, depending on which side of the break they place themselves and their generation. ${ }^{39}$ That is to say, they may be either apocalypticists, if they see

37 Dmitri Obolensky, "Rus- kul'turnom osveshchenii," Trudy sia’s Byzantine Heritage,” in The Structure of Russian History, ed. Michael Cherniavsky (New York: Random House, 1970), 3-28.

38 B.A. Uspenskii, "Kul't Nikoly na Rusi v istorikopo znakovym sistemam [Uchenye zapiski Tartuskogo Gos. Univ.] 463 (1978): 86-140.

39 Cf. Sergei Bulgakov in "Pravoslavnaia eskhatologiia": "Eschatologism may have two images [dva obraza], light and dark. The latter has its place when it arises as a result of historical fright and a certain religious panic: it was this sort [of eschatologism that was produced by] the Russian schismatics - the 
the present transitus as an ultimate judgment "from beyond" on their fallen fellows (as well as a simultaneous vindication of their own faith), or utopians (or millenarians avant le lettre), if they see contemporary reality simply as a stage to pass through in order to reach that "no place" which passes for a terrestrial New Jerusalem. Thus, although there are countless permutations and no hard-and-fast laws in these matters, the apocalypticist tends to interpret the old/new opposition by making the first element positive (the original, pristine faith) and the second element negative (contemporary impiety and desecration), while the utopian tends to do the reverse, making a fetish of what is new, "enlightened," "advanced," such as technology (usually seen in Russia's case as coming from the West), and denigrating what is old, "superstitious," and "ignorant," such as religious tradition (usually seen in. Russia's case as indigenous). $4^{\circ}$ Ultimately, however, the apocalypticist and utopian cannot be said to translate simply into opposite sides of one eschatological coin; they have radically different conceptions of what constitutes narrative authority in the historiographical process. To the one, this authority comes from God, who is outside human (hi)story; to the other, this authority comes from human beings, who can make themselves and their ideal POLIS within history, if only they really try.

While our focus in these pages is primarily the nineteenth century and that "prehistory" of Russian apocalyptic consciousness leading up to Dostoevsky and the modern period, I would like to dwell briefly on several episodes from earlier Russian history. These episodes loom large because over time they became a fertile source for the kind of end-determined,

self-immolators who wanted to destroy themselves in order to save themselves from the reigning Antichrist. But characteristic of eschatologism can be (and should be) a bright image with its impulse toward the Coming Christ. As we proceed in history, we come to meet $\mathrm{Him}$ [idem $\mathrm{k}$ Nemu navstrechu], and the rays [of light], emanating from His future coming to the world, can be felt... Thus the Second Coming of Christ is not only terrible for us, since $\mathrm{He}$ will come as our Judge, but also glorious, since He will come in His glory, and this Glory is also the glorification of the world and the fullness that has come to pass in all creation" (Sergii Bulgakov, prot. "Pravoslavnaia eskhatologiia," Pravoslavie: Ocherki ucheniia pravoslavnoi tserkvi [Paris: YMCA, 1985], 385).
40 Utopians can, to be sure, select as a model a golden agrarian age in the past, but I have in mind those - Alexander Bogdanov and Alexei Gastev would be prime examples in the modern Russian context who take the streamlined euchronia, the "high tech" urban center, as the destined goal of history. See the Manuels (Utopian Thought, 20) for the difference between "eutopia" and "euchronia": "In the bosom of a utopia of agrarian calm felicity a utopia of endless, dynamic change in science and technology was born. This switch to euchronia was heralded with the awakened sleeper of Sébastien Mercier's L'An 2440 and with the utopian projections in the Tenth Epoch of Condorcet's Esquisse. The vision of a future society of progrès indéfini predominates through the emergence of Marx on the utopian landscape. Paradoxically, un-Christian utopia represented a resurgence of a strong millenarian, paradisaical, and apocalyptic current in secular form. The free rational choices of the Morean Utopian lawgiver or the Renaissance architect were abandoned to history: Utopia became less Hellenized and more Judeo-Christian. Older rhythms of thought from millenarianism and Joachimism were secularized, and translations of Judeo-Christian apocalyptic rhetoric into new forms became the stuff of the transformation." Again, on the parallels between utopia and apocalyptic paradise, see Utopian Thought, 33-63. 
"right- angled" view of national history perpetuated by later writers, social theorists, and public figures. Moreover, they have striking similarities that gradually entered into the Russians' myths about themselves, their nation, and their ruler. The first has to do with the formula "Moscow the Third Rome," and, while generally traceable to the pronouncements of the Pskovian monk Philotheus in the early sixteenth century, ${ }^{41}$ encompasses a larger series of dates and events: the Council of Ferrara-Florence (1438$39)$, the fall of Constantinople in 1453, the projected end of the world in 1492, the writings of Philotheus c. 1510-24, and the crowning of Ivan IV as tsar in 1547. The second involves the Great Schism of the 1660 s and the Petrine reforms which followed in the early years of the eighteenth century. These two constellations of events are not only related to each other but are seminal to an understanding of Russia's historical identity before its writers of secular history, such as Karamzin, began to try to disentangle the myth from the reality. It was these myths, whose precise historical provenance was often forgotten or ignored, that those coming after either tried to live up to or to live down, but rarely reacted to neutrally.

54. An essential element of Byzantine ideology inherited by the Russians was the notion of basileus, of the emperor who is simultaneously spiritual and secular leader of his Christian realm..$^{42}$ Even though the basileus is largely a "messianic" concept, ${ }^{43}$ it does have important ties with the Eastern Christian apocalyptic tradition through the Revelations of the PseudoMethodius (wr. late seventh century). According to the latter, there would appear a Last World Emperor, whose role it was to defeat the Ishmaelites (read Islam) and then journey to Jerusalem to hand over his crown to God, at which moment the time of the Antichrist would commence. ${ }^{44}$ The basileus myth itself goes back to Constantine $(288$ ? - 337), who united Christianity and imperial Rome during his reign and built a new capital in Byzantium, which was renamed Constantinople and which, from the latter part of the fourth century, came to be known as the

41 Evidence for the emergence of the myth of Moscow the Third Rome can be found in texts that pre-date Philotheus' formulation, such as "The Tale of the White Cowl” (late fifteenth century), but it was Philotheus who first made the case explicitly and concisely ("Both Romes fell, the third endures, and a fourth there will never be" [cited in Sergei A. Zenkovsky, Medieval Russia's Epics, Chronicles, and Tales (New York: Dutton, 1974), 323]).

42 The attributes "spiritual"/"secular" were origi- nally not opposed, but merely different profiles of one divinely inspired countenance. See Michael Cherniavsky, "Khan or Basileus: An Aspect of Russian Mediaeval Political Theory," in The Structure of Russian History, ed. Michael Cherniavsky (New York: Random House, 1970), 65-79; and Obolensky, “Russia’s Byzantine Heritage.” For much of this discussion of Philotheus, I am indebted to Stremooukhoff's fine study of Moscow as the "Third Rome” (Dimitri Stremooukhoff, "Moscow the Third Rome: Sources of the Doctrine," in The Structure of Russian History, ed. Michael Cherniavsky [New York: Random House, 1970], 108-25).

43 McGinn, Visions of the End, 28.

44 Ibid., 70-73; see also Paul J. Alexander, Byzantine Apocalyptic Tradition, ed. Dorothy deF. Abrahamse (Berkeley: University of California Press, 1985), 13-6o.

45 According to the prophetic script of the pseudoMethodius, Constantinople was to be liberated by the Last World 
"New Rome." This second, "Eastern” Rome acquired additional status when the first, "Western" Rome was sacked by Alaric in 410. But by the fifteenth century Constantinople, which up to then had been successful at fending off Eastern marauders, was itself under imminent threat of falling to the Ottoman Turks. Its church delegates were eager to strike a bargain with a now renovated Rome at the Council of Ferrara-Florence. Moscow, on the other hand, which for some time had seen the rival Latinists as "old," "corrupt," "Sallen," and "Western” (especially after the excommunication of Michael Cerularius, patriarch of Constantinople, and the resulting schism of 1054) interpreted the union as perfidy. The actual fall of Constantinople in 1453 became proof a fortiori both of God's displeasure and of the Russians' own elect status. Already profoundly under the spell of messianism through the imported concept of the basileus, Moscow was soon faced with the prospect of either liberating Constantinople (thereby fulfilling its role as the "fair-skinned tribe" in the prophetic script of the pseudo-Methodius) ${ }^{45}$ or declaring itself the third and last Rome and its tsar ${ }^{46}$ the basileus. When the end of the world did not occur in 1492 (the last year of the seventh millennium in the Byzantine calendar), Moscow was free to pursue the second alternative.

Strangely enough, the fall of Constantinople, the passing of the year 1492, and the rise of Moscow as the Third Rome were essentially a reading of the Christian plot or mythos into contemporary history, but with a different twist. History was not yet secularized, and thus its meaning had still to come from outside. What could be "apocalyptic," or a justification for negative happenings, in the case of Constantinople could also be "messianic," or a justification for "chosen" status, in the case of Moscow. ${ }^{47}$ This distinction is borne out with remarkable vividness in the exegesis of Philotheus. Taking his cue from earlier remarks by Zosimius, metropolitan of Moscow, and borrowing his figures from the Apocalypse of Ezra, ${ }^{48}$ Philotheus identifies the third head of the twelve-winged eagle (IV Ezra 12:23) with Moscow, which had recently coopted the two-headed eagle as its coat of arms. Yet Philotheus is also apparently aware that this image of a three-headed beast could have negative connotations, such as the passing of worldly empires on the model of Daniel's four beasts. Thus in the epistle "Against the Astrologers and the Latins" (c. 1524) he shifts his emphasis from the third head of the eagle to the Woman Clothed in the Sun (Revelation 12:2), whom he perceives as Russia fleeing into the desert

Emperor and his fair-skinned tribe, after which the final confrontation with the Antichrist would take place and the End of the world would follow (Sackur, Sibyllinische Texte, 89-94; cited McGinn, Visions, 75-76).
46 The title began to gain currency under Ivan III (ruled 1462-1505).

47 On the distinction between "messianism," "millenarianism," and "apocalypticism," see McGinn, Visions 28-36.
48 The Apocalypse of Ezra was itself based in part on the Book of Daniel, an important Old Testament apocalyptic text. See Stremooukhoff, "Moscow the Third Rome,” 113. 
of true faith away from the false capitals of Rome and Constantinople. What is particularly striking about this case being made for Russia's manifest destiny is that Philotheus was arguing, like a Russian Augustine, against his native Pskovians, who saw Moscow as the seat of the Antichrist (Pskov had recently fallen under the rule of Vasily III, who deprived the ancient city of its rights and dispersed much of the population), and against the Latins, who maintained that the true Christian empire was still located in the West.

When Ivan IV had himself crowned tsar in 1547 amid much pomp, 49 he in effect consolidated the notion of Russia as holy empire and himself as basileus, which latter fact was soon recognized by the Eastern church. Indeed, beginning with the early sixteenth century scribal attempts were made to trace the Russian princely dynasties back to Augustus via his brother Prus, ruler of Prussia; this meant that these princes "were heirs of the two Romes not only spiritually or eschatologically, as they were for the monk Philotheus, but historically, virtually dynastically."50 Moreover, the shift from saintly prince, with his filial, "Christ-like” role, to pious tsar, with his paternal, "God-like” one, was not lateral but vertical.

56. It was, concludes Cherniavsky, "a raising of his functions to a higher, apocalyptic level; his person could not be made more exalted in any case." ${ }^{51}$

With the coming of the Great Schism in the next century, the terms of spatiotemporal opposition remain essentially the same, but their values are reversed. The questions of ritual and doctrine now, as in the cases studied by Cohn in Northern and Central Europe, have an ever stronger social undercurrent. It is as if the Pskovians' cries in the wilderness, which in their time were limited to one or two cities (Novgorod also experienced apocalyptic forebodings in the early sixteenth century), had spread to a larger area and begun to rival in resonance the voices of official doctrinal reason. The Old Believers, it should be recalled, made their case to a significant portion of the population, with as many as twenty percent of the Russians of the time joining their ranks and embracing the political theology of the Schism.52 Above all, Avvakum and his followers were a sectarian movement that saw their golden age of harmony and piety in the past. As Berdyaev writes, "The Schism was a departure from history because history was controlled by the prince of this world, the Antichrist, who had penetrated to the upper levels of the church and state. The Orthodox kingdom was going underground. The

49 This was, to be sure, not the first time that a Muscovite grand prince had borne the title but it was the first time that the crowning had been surrounded by such august celebration.
50 Michael Cherniavsky, Tsar and People: Studies in Russian Myths (New Haven: Yale University Press, 1961), 42.

51 Ibid., 40.
52 Michael Cherniavsky, "The Old Believers and the New Religion," The Structure of Russian History, ed. Michael Cherniavsky (New York: Random House, 1970), 4-5. 
genuine kingdom was the City of Kitezh [a popular version of paradise], located beneath the lake." 53 Hence the seventeenth century in general and the decade of the Schism in particular were times of great social upheaval, including the civil wars of the Time of Troubles, the peasant unrest in the 1630s, the town rebellions in the 1640 s and 1650s, the Cossack uprisings in the 1660 s and 1670 s, and the streltsy fronde in the 1680 s and 1690 s. Indeed, it would be no exaggeration to say that the Schism and the Petrine reforms (which the Old Believers led the reaction against) were the moment in Russian history when the oppositions of old/new and east/west entered into a particularly fateful alignment with the Russians' myths about themselves and the governance of their state. The very facts of broad popular appeal and interpenetration of the political, social, and theological realms suggest that this time was perceived as a "turning point" not only for the Avvakumians but for all those coming later who, with the emergence of "historical consciousness" in the early nineteenth century, would wrestle with their country's identity as "Eastern" or "Western," as a renovation of a golden past or a radical thrust into an enlightened future. The replacement of Moscow the Third Rome by St. Petersburg, the secular Western city of the Antichrist, would become a central theme, for example, of The Idiot and Petersburg, two of the "apocalyptic fictions" to be treated in this study; both pre-1917, these works present imperial Russia fast entering a state of crisis and eclipse. Similarly, the fate of the original capital, renovated to its former status after the revolution, would be the subject of The Master and Margarita and Doctor Zhivago, novels that show the city as a parodic Whore of Babylon and a fallen (and ultimately risen) Third Rome, respectively. 54

If the apocalyptic mood in medieval Russia never disappeared entirely, it reasserted itself with a vengeance in 1644 , when the government printing office released the so-called Book of Cyril, which contained various South Slavic and Ukrainian apocalyptic writings. It was at approximately this same time that the monk Kapiton, founder of a hermitage in the north (Totma), first began to spread his theology - known pejoratively as kapitonovshchina - of flight from this world, imminent apocalypse, and self-immolation. ${ }^{55}$ Kapiton's activities served as a prelude to those of the Old Believers three decades later; an important shift in political theology was augured by the claim, made by one of his followers, that Tsar Alexis (ruled 1645-76) was "not tsar but a horn of the Antichrist."56

53 Berdiaev, Russkaia ideia, 14 .

54 Dostoevsky's The Idiot, Bely's Petersburg, and Pasternak's Doctor Zhivago are several of the texts analyzed in The Shape of Apocalypse (see note 1 above).
55 Cherniavsky, "Old Believers," 16.

56 la.L. Barskov, Pamiatniki pervykh let russkogo staroobriadchestva (St. Petersburg: Tip. Alexandrova, 1912), 333; see also P.S. Smirnov, Vnutrennie voprosy $\checkmark$ raskole $v$ XVII veke (St. Petersburg, 1898), 31 f..
57.

Chapter 2 
In this cryptic comment we already see the beginnings of an assault on the myth of basileus that will be carried far and wide by the old Believers. The apocalyptic expectations of kapitonovshchina began to heat up again when the Patriarch Nikon decreed changes in church ritual in 1652-54. These reforms in ritual, which affected the way one made the sign of the cross, the number and manner of prostrations, and the hallelujah glorification, were not the first undertaken at the initiation of a tsar; 57 along with the abovementioned social tensions, however, their endorsement of Greek and South Slavic "purity" held the match to the powder keg of broad reaction. At first, the small group of Moscow preachers led by Avvakum was kept in check, but they persisted in their ecclesiastical rebellion. Attempts at compromise were rebuffed by the Avvakumians - the Fathers Avvakum, Fyodor, Lazar, and Epiphany - and the Patriarchal Council of 1666-67 passed intact the Nikonian reforms and declared the "old" practices and texts heretical. Those who continued to resist were anathematized, while the Avvakumians themselves were exiled to the far north (Pustozersk), where, in 1682, they were burned at the stake.

58. This skeletal account gives little sense of how closely apocalyptic theology was intertwined with the Council's work and the subsequent fate of the Avvakumians and their converts. ${ }^{58}$ The Schism forced the Old Believers to rethink the essential terms entering into their Russian understanding of the economy of salvation. If Moscow was turning its back on its heritage as the Third Rome, then there was only one conclusion to draw - it was not the holy but the unholy city, the seat of the Antichrist. Nikon and Tsar Alexis were precursors of the Antichrist, whose appearance was scheduled for 1666 (the date of the convening of the Council and a convenient cipher for the beast's number, 666 [Revelation 13:18]). Messianism was turned inside out into apocalypticism; Russia's manifest destiny as the New Rome and world savior was transformed into its manifest destiny as traducer of sacred (here "old") tradition, as the Antichrist. In the words of the Old Believer monk Avraamy, "There will no longer be any further delay; everywhere is Russia's last [moment], and from hour to hour worse things happen."59

57 Witness Ivan IV's wellknown Stoglav Council in 1551.

58 To shift the context a little, the Great Reform movement - the West's version of the Schism - which originated in Luther's Germany a century and a half earlier and soon spread to Calvin's Geneva and Zwingli's Zurich, involved a quite similar apocalyptic theology. Only the terms, not perhaps unexpectedly, were reversed: the Wittenberg preacher (who, like Avvakum, was excommunicated in 1521 for insisting that popes and their councils can err) stood for "newness" - for a translation of the Bible into colorful German vernacular, for congregational singing, for lay reception of the eucharistic bread and wine, etc.; the traditions of the Roman Catholic church, especially those connected with the practice of granting indulgences were seen as "old"-as belonging to the temporal rather than the universal church, to the Antichrist rather than Christ. Of course Luther, like most late medieval Christians, fully believed that his children would live to see the Second Coming.

59 Barskov, Pamiat- 
By the late seventeenth century the Old Believer movement had spilled over into the impressionable, often uneducated public far beyond anything imagined by the original group of four. Numerous zealots were writing hundreds, if not thousands, of apocalypses of their own, preaching fiery sermons in the northern woods, and, when hemmed in too closely by the authorities (in 1684 it was made a secular, state crime, with punishment of death, to practice the schismatic faith), burning themselves alive to protest this world. Equally significant, these same starovery provided important ideological impetus for popular rebellion: consider, for example, the now generally acknowledged connection between the Old Believers and the revolt of Stenka Razin in 1670-71 and the uprising of the streltsy in 1682. And so, "beginning with the insurrection of 1682 , every popular uprising in Russia - the continued streltsy troubles, the Cossack rebellions under Peter I (Azov, Astrakhan, Bulavin's uprising), and the climax of the great uprising of Pugachev under Catherine II - was fought under the banner of the Old Belief: the restoration of old rituals, icons, and books was inextricably connected with the program of massacring the aristocracy and abolishing serfdom."6o

In other words, with the coming to power of Peter I (ruled 1682-1725), the fury of the Old Believers' apocalypticism reached its peak and the true raskol began. Peter, who spelled his name with a foreign alphabet, was seen as the Antichrist incarnate; his city, with its Western architecture, its predominance of European spires over Orthodox cupolas, as un-Russian and thereby unholy; his new calendar, which "stole eight years from God," as a turning away from Biblical time; and his chosen title - imperator (emperor) - as the ultimate derogation of his sacred role as tsar. Peter's desacralization of Russia's past went much further than the shearing of boyars' beards - the number of variations on the Peter as Antichrist myth attests to this. But the main issue remained one of divine genealogy: as basileus, Peter was supposed to be God's appointed servant on earth; yet rather than accepting this role, he had made of himself a zemnoi bog, a god on earth. ${ }^{61}$ It is indeed ironic that the Old Believers were so devoted to the "old," including the belief in their ruler as basileus, that they devised stories about Peter's changeling status. After all, to them this colossal figure of evil could not be both tsar and Antichrist.

The seventeenth century was not only a time of great turmoil for the myth of the tsar as basileus, however. It was also the time when the second great myth, that of "Holy Russia” (Sviataia Rus') and her

60 Cherniavsky, "Old Believers," 20. To glance ahead for a moment, both Blok and Bely, in the years leading up to 1917 , would become fascinated by the tradition tying together apocalypticism, revolution, and sectarian heterodoxy. After 1917, writers such as Pilnyak and Platonov would translate the same apocalypticist-sectarian nexus into Bolshevik legend: the former's okhlomony (Mahogany) and the latter's Chevengurians are in fact modern Old Believers who are attempting to keep the faith of the revolution alive in times of compromise and "secularization” (the NEP - New Economic Policy).

61 Ibid., 33. 
people (narod), first gained wide currency as something independent of, and indeed in many ways opposed to, the myth of the tsar. ${ }^{62}$ As Alexander Solovyov first established, the term “Holy Russia” initially appeared in Prince Andrei Kurbsky’s correspondence with Ivan IV as an indictment of the tsar's action - the émigré prince lamented that Ivan had "dishonored [himself] and the holyrussian land."63 But only with the Time of Troubles (Smutnoe vremia) in the early seventeenth century, when Russia was without a tsar and had to preserve its Orthodox essence intact against Polish Catholic intervention, did the term gain popular acceptance and begin to appear in numerous folk songs and epics:

Russia was "Holy Russia" because it was the land of salvation, expressed in its icons, saints, people, and ruler. But the historical origin of the term indicates its concrete limits: "Holy Russia" was what remained, during the Time of Troubles, after Tsar and State and church hierarchy were gone; it was the concentrated essence of Russia, visible when the form of Russia was destroyed. Hence, both on the transcendental and con-

60. crete levels "Holy Russia" was an absolute, immutable, because the land of salvation could not change except catastrophically, nor could the Russian essence change without losing itself. ${ }^{64}$

Here was a spatial myth that existed "no-place" but was capable of sustaining those like the Old Believers as they confronted the specter of tsar turned Antichrist and the Third Rome turned Whore of Babylon. Where, one might ask, could this "Holy Russia" be found? It could be found in the narod, in the villages and monasteries, lower gentry and simple folk that kept the faith alive when the tsar was absent and the Poles were at the gates of Moscow. So too could it be found in those preachers in the northern woods who burned themselves alive because their tsar had disappeared and because the only way back to the past, to the underwater kingdom of Kitezh, was through fery death. Thus "Holy Russia," though born of a specific time and place, became something nonhistorical, transcendental. Rus', the name for "old” Russia, could be Sviataia, "Holy," but the Imperiia, "Empire," could only be Rossiiskaia, a secular "Russian" formed from the "new" noun Rossiia. ${ }^{65}$ And it was between these two essentially opposing myths, that of the tsar and that of the people of "Holy Russia," that the intelligentsia, the group of educated Russians who were located

62 It could conceivably be argued that the notions of "Russian Land" (russkaia zemlia), dating back to Kievan times, and "Holy Russia” are analogous. Here, however, the operative term is holy, which was first joined with
Rus' in the sixteenth century, in Kurbsky's correspondence. Paszkiewicz links the older term Rus' and the Christian religion, but without the specific use of sviataia (Henryk Paszkiewicz,
The Origin of Russia [New York: Philosophical Library, 1954], 12).

63 Russkaia Istoricheskaia Biblioteka, vol.31, Sochineniia Kniazia Kurbskago (St. Petersburg, 1914), 134; cited in Cherniavsky, Tsar, 107. 
outside either myth, ${ }^{66}$ found themselves when, returning obsessively to the question of Russia's identity, they made cultural history in the nineteenth century.

It would be futile to try to define with any precision "Holy Russia” and its ephemeral boundaries within the narod. What can be proposed is that the term, as a cultural model, inevitably raises issues of mythical, as opposed to historical, time. Each of its later champions - Khomyakov, Zhukovsky, Vyazemsky, Tiutchev, Dostoevsky, Fyodorov, Berdyaev was forced to accommodate a contingent, problem-ridden present by casting back to this nonhistorical past or by projecting it into the future. Moreover, the moment in Russian cultural history at which this all-important opposition became actual and operative, entering into the very structure of the Russian language, was again the seventeenth century, the same epoch-making period of the Schism. The Soviet scholar A.M.Panchenko has demonstrated that, beginning with the second half of the seventeenth century, one can add to the already familiar oppositions of old/new and foreign/domestic the new opposition of mythical time/secular history. This may seem, prima facie, simply another variation on the old/new antinomy, but Panchenko thinks otherwise. The grounds for argument between Nikon and Avvakum were not necessarily tradition and innovation in a true historical sense (since in matters of ritual and doctrine almost any scriptural source can be adduced to buttress the priority and hence the authority of one's argument); on the other hand, the grounds for argument between the traditionalists and the new teachers of imported baroque culture who came to prominence during the reigns of Tsars Alexis and Peter could, and probably did have, considerable import for the development of Russian historical consciousness. In this case, the polemic between the Old Believers and such "New Enlighteners" as Simeon of Polotsk, Silvester Medvedev, Stephan Yavorsky, and St. Dimitry of Rostovsk was not so much over doctrine - though that was the pretext - as over historical time. "It was not a historiographical but a historiosophical argument - an argument about a historical ideal, about historical distance, about the interrelation between man and time, about eternity and the perishable, about the past, present, and future." ${ }^{\prime 67}$

Using an approach not unlike Lotman's, Panchenko breaks these two conceptions of time into the medieval, that valorized by the Old Believers, and the proto-modern, that valorized by the New Enlighteners. The first sees

64 My emphasis: Cherniavsky, Tsar and People, 116

65 Ibid., 119.

66 Generally speaking, the intelligentsia saw themselves as belonging neither to the tsar's reactionary government nor to the narod's difficult daily life and customs. See below.

67 A.M. Panchenko, “Istoriia i vechnost' v sisteme kul'turnykh tsennostei russkogo barokko," Trudy otdela
61.

Chapter 2 
"human existence, taken in toto, as an echo of the past-more precisely, of those events from the past which are identified with eternity." ${ }^{68}$ This "echo" is intimately bound to the Orthodox understanding of weekly and yearly cycles, each of which "renews," in small or large scale, the resurrection of Christ. Within the family circle (or "cycle"), the same echo principle was at work: individual members, as descendants, were often given names from one semantic "family" to underscore the belief that their role was to recapitulate the "clannish fate" (rodovaia sud'ba) of their ancestors. Here the renewal is never innovative, never a break with the past, but always a reconfirmation of human contact with eternity. In other words, Panchenko's revealing analysis is in remarkable accord with what Eliade has written about sacred time in archaic or primitive societies. The future does not yet exist (hence the Apocalypse for the Old Believers is now) because the profane present is constantly annulled in favor of a periodic return to eternity. According to Orthodox ritual, the "man who fasts, confesses, and takes communion each time 'renews himself.' That is, he purifies himself of sinful [outer] layers, grows closer to the ideal. 'Renewal' is a kind of 'aging' [odrevlenie: lit: 'making anci-

62. ent'] of man, in which the qualities of the ideal show through with greatPARTI er clarity." ${ }^{69}$

For the New Enlighteners, however, many of whom had been through the Kiev Academy and were influenced by Polish (that is, "Western," post- Renaissance) models, historical time was not something to be banned; rather it was something to be learned and understood. These were men of books and libraries, whereas Avvakum was a man of one book in principle and few books in practice. When, for example, the latter was blessed early in his career by a confessor, the formula used included "by the [apocalyptic!] Book of Ephrem the Syrian."”o This is not to say that the culture of the Old Believers was one of ignorance and obscurantism, as Simeon and his colleagues would submit, but simply that the book, like the icon, was something sacred, immutably true, in no need of duplication. The book, and the Great Time of which it told, possessed human beings; human beings did not possess the book. With the Enlighteners, on the other hand, the Russian, to use again Eliade's formulation, entered history as secular time. To be sure, this was not seen by them as a "fall" into history - quite the opposite, since Russia was being raised out of the darkness - but it would seem so to later, more nostalgic, generations. These scholars "proclaimed the idea of a unified, civilized time, removing, in effect, the distinction

68 My emphasis: ibid.

69 Ibid., 192.

70 Cited in Panchenko,

“Istoriia i vechnost'," 194. 
between eternity and perishable existence"; history became "interesting' in and of itself, independent of its relation to God, eternity, and the soul"; and history, most importantly, no longer "predetermined the fate of [one's] descendants, their earthly existence. The past was dead." ${ }^{11}$

Not fortuitously, the gradual emergence of secular literature, as well of its disguised forms in the works of those still closely associated with the church, marked this shift in historical consciousness. Simeon's verse play written in the 1670 s provide compelling evidence of the change in process. The first, about Nebuchadnezzar, would appear by its title to be an adaption of the church ritual then referred to as chin peshchnogo deistva (lit. "rite of the furnace action"). ${ }^{72}$ It was this ritual, which took place at Christmastime and symbolically recalled the immaculate conception (just as the youths were not burned in the furnace, so was the Virgin not harmed by the fiery Holy Spirit entering her natural body), that the tsar himself had traditionally participated in. Now, however, it was subject to ban, and consequently Simeon's play has none of this symbolic overlay. In fact, the principal focus of the play is the "comedic" (plays at this time were called komedii), "verisimilar" historical parallels between the ancient king and the current Tsar Alexis. Hence the faith (vera) implicit in the Christmas ritual (chin) was being eroded by the culture of the "comedy." ${ }^{73}$ The similarities (and differences) between Nebuchadnezzar and Alexis served to indicate how future generations would interpret the deeds of the present tsar. History began to stretch out into the future, to appear endless. Even questions of the Last Judgment, which so vexed the Old Believers, became more personal than collective, more "literary" than "literal." The numerous works of the Russian baroque that deal with the Apocalypse - the "Pentateugum" of Andrei Belobotsky and the anonymous "Staircase to Heaven" are two of the best known - do so thematically rather than ritually. Conversely, the actual ritual during Shrovetide - when the patriarch wiped clean the icon of the Last Judgment in the Uspensky Cathedral (the act of "renewal") and blessed and sprinkled water over the tsar-was abolished. Like Augustine defending his church and faith against the apocalypticists, St. Dimitry, one of the New Enlighteners, could claim: "To us the Last Judgment is more personal [komuzhdo svoi] than general, and as for the time itself of the terrible judgment day, it is not for us to ask. It is enough to believe that it will come... but when it will come, do not inquire... about that day and hour no one knows." ${ }^{74}$

71 Panchenko, "Istoriia i vechnost'," 195.

72 See Simon Karlinsky, Russian Drama from its Beginnings to the Age of Pushkin (Berkeley, CA: University of California Press, 1985), 1-14.
The actual title read: Of the King Nebuchadnezzar, the Golden Calf, and the Three Youths Not Burned in the Furnace.

73 Panchenko, "Istoriia i vechnost'," 196.
74 Rozysk o raskol'nicheskoi brynskoi vere 62; cited in Panchenko, "Istoriia i vechnost'," 198. 
Russia's transition from theocratic to secular state was obviously more complex and continuous than our schematic retelling of it allows, yet in the final analysis there is no minimizing the vast significance of the Petrine reforms and the figure of Peter himself. Nineteenth-century social thought and historiography abound with comparisons, optimistic and pessimistic, utopian and apocalyptic, that interpret the present and predict the future by attempting to solve the riddle of the Petrine Sphinx. Even such a respected historian as S. M. Solovyov considered Peter "the hero of Russian history, probably the only hero, and the last one... [He] concludes the epic period of Russian history and opens the era of civilization for Russia... The change under him was most ra dical: from epic to history - from prehistory to history proper. Only since Peter has Russia become an 'historic' nation."75 This is a gross oversimplification, as most modern historians would now admit, but again, as a cultural model and narrative mythos to be strenuously rejected (the Slavophiles) or equally strenuously embraced (the Westernizers), it maintained its potency into the nineteenth century and, in some cases, beyond.

64. Thus flanked by an "enlightened" vanguard whose task it was to legitimize the tsar's role, the Petrine myth emerged in its purest form as a tale of long overdue change - not evolutionary, but revolutionary, not ameliorative, but total, instantaneous, seemingly ex nihilo, and of course eschatological. Antiokh Kantemir proclaimed that through the "wise commands"of Peter Russia had become, "in a moment's time," "a new people."76 And just as Simeon had earlier compared Alexis to Nebuchadnezzar, so now Feofan Prokopovich compared Peter to Saint Vladimir, the Christianizer and "enlightener" of Russia, in his tragicomedy of the same name. ${ }^{77}$ "New" suddenly had a positive valence, as it had for Hilarion, and what was "old"including the obstreperous Orthodox priests thinly disguised as "pagan sorcerers" in Prokopovich's play - was ignorant and evil. ${ }^{78}$ In effect, the notions of progress and enlightenment championed by the new cultural spokesmen carried with them the spatial image of futurity, the put' (path) that was to become the root metaphor for directing and marshalling the "historical present" (ultimately a contradictio in adjecto) in the collective imagination of the emerging intelligentsia. What was totally "new" or "reborn" had to go somewhere, to look for something. Disenfranchised by Peter's meritocracy and table of ranks and raised on a steady diet of "progressive" European principles, the hereditary nobility (stolbovoe

75 Cited in Georges Florovsky, "The Problem of Old Russian Culture," The Structure of Russian History, ed. Michael Cherniavsky (New York: Random House, 1970), 127.
76 My emphasis; Antiokh Kantemir, Sobranie stikhotvorenii (Leningrad: Sovetskii pisatel', 1956), 75. Compare, for example, the following lines about Stalin written by the Georgian poet N. Mitsishvili in the mid-thirties and translated by Pasternak: "You have achieved the unachievable: / You have remade [peresozdal] people's minds and souls, / Your hand with sickle has covered a continent, / And with hammer has gone to the ends of the earth" 
dvorianstvo) were to become leading members of the intelligentsia and the creators of the new literature. Not only did they see their own power and wealth ebbing away, they were forced to witness the decline of their peasants, the principal victims in this political and economic realignment. ${ }^{79}$ "The Russian nobleman of the nineteenth century normally lacked strong roots in any particular area and had no real feeling of attachment to a specific locality and to a family estate on which his ancestors had lived for generations... There is little evidence of the attachment to and the ties with the ancestral home which characterized the mentality of the western nobleman." ${ }^{80}$ Reared by nursemaids and tutors who had no "rights" to him, sent to a school which offered a completely Western education, the young nobleman grew up with a distinctly rationalistic and didactic cast of mind, neither totally Muscovite nor French, but one that obviously anticipated that of the nineteenth century intelligent. ${ }^{81}$ In a word, the educated nobleman of the eighteenth century found himself "doubly cut off: from his own people's past, which he had learned to scorn and reject, and from Western Europe, which had not yet fully accepted him and of which he still did not feel the equal." ${ }^{2}$

The almost hypnotic attraction of the put', with its spatialization of temporal desire, is an essential ingredient in the messianic and apocalyptic roles that the nineteenth-century intelligentsia assigned to the longsuffering narod. It was felt that the various roads, paths, and ways invoked to describe Russian historical time should in the end, and at the end, have a destination. With remarkable ingenuity, the present was overcome by finding some popular trapdoor to a sacred - usually prePetrine - past or by scaling the ladder of Western, post-Enlightenment knowledge to a brighter future. Yet in either case the temporal ideal was equally removed, equally distant from the intelligent "outsider." Berdyaev, whose own work grew out of the late nineteenth-century tradition, resorts to the same matrix of images (spatiality standing in for temporality) when he states with characteristic aplomb that "Russians

(Poéty Gruzii v perevodakh B.L. Pasternaka i N.S. Tikhonova, ed. N. Mitsishvili (Tiflis: Zakgiz, 1935), $85-86)$.

77 Lotman and Uspenskii, “Binary Models," 52-56; see also Karlinsky, Russian Drama, 24-29.

78 It is significant that the opponent of the pagan sorcerers is not a churchman but a Greek philosopher. See Karlinsky, Russian Drama 26.

79 Iu.M. Lotman, “Ideinaia struktura 'Kapitanskoi dochki', "Pushkinskii sbornik (Pskov:
Pskovski Gos. Ped. Institut, 1962), 3-20.

8o Marc Raeff, "Home, School, and Service in the Life of the Eighteenth-Century Russian Nobleman," in The Structure of Russian History, ed. Michael Cherniavsky (New York: Random House, 1970), 295-307.

81 Henry L. Roberts, "Russia and the West: A Comparison and Contrast," in The Structure of Russian History, ed. Michael Cherniavsky (New York: Random House, 1970), 256.
82 My emphasis; Marc Raeff, “Russia's Perception of Her Relationship with the West," in The Structure of Russian History, ed. Michael Cherniavsky (New York: Random House, 1970), 262-63. 
are beguny [a sect whose name means "runners," those running from this world] and bandits. And Russians are wanderers [stranniki] in search of God's truth." 83 It is only a short step from this account of the sectarian genesis of Russian restlessness and "flight" to a general spatialization of the urge for temporal reintegration experienced by all great Russian writers:

Russians always thirst for another life, another world; they always experience displeasure at what is. There belongs to the structure of the Russian soul an eschatological directedness. The urge to wander [strannichestvo] is a very characteristic Russian phenomenon, and as such unknown to the West. The wanderer walks the boundless Russian land and never settles down [osedaet], never becomes attached to anything. The wanderer searches for the truth, for the Kingdom of Heaven; he is directed into the distance. The wanderer has no abiding earthly city, but is directed toward the City-to-Come [Grad Griadushchii]. The people [narodnyi sloi] have always singled out from their midst such wanderers. Yet in spirit the most creative representatives of Russian culture - Gogol, Dostoevsky, L. Tolstoy, Vl. Solovyov, and all the revolutionary intelligentsia - have also been wanderers. There exists not only a physical, but a spiritual urge to wander. This is the inability to be at ease with anything finite, the directedness toward what is infinite. But this is also an eschatological directedness, an expectation that there will be an end to all that is finite, that a final truth will be revealed, that in the future some sort of extraordinary occurrence will take place. I would call this a messianic sensibility, to an equal degree characteristic of those [coming] from the people [narod] and of those of higher culture. Russians are, to a greater or lesser extent, consciously or unconsciously, chiliasts. Westerners are much more sedentary [osedlye], more attached to the perfected forms of civilization; they value their present and are more concerned with the successful management of the earth. ${ }^{84}$

As is often the case, Berdyaev's generalizations could be relegated to the musty files of Geistesgeschichte were it not for the influence such notions had on leading nineteenth century thinkers, who in turn, with their own mix of mythos- and political agenda, cast an imposing shadow on the

83 Berdiaev, Russkaia ideia, 10.

84 Ibid., 199. 
"authors" of the revolution at the turn of the twentieth century. One need only recall how attached Lenin was to his executed brother's copy of What Is to Be Done? (1863), ${ }^{85}$ itself a kind of utopian fairy tale with an ideal future (cast in the present) and a plucky Cinderella (Vera Pavlovna) who wins both her prince and her happy kingdom (a Russian version of the Fourierian phalanstery) in the bargain. From the late eighteenth to the early twentieth century nearly every major historian, philosopher, and author (as well as countless minor ones) tried to come to terms with the familiar old/new, east/west oppositions, and, as social tensions increased and anarchy and revolution became more probable, they saw the conclusion to the historical plot rise into view either as a utopian triumph devoutly to be wished or as an apocalyptic ekpyrosis (great fre) or kataklysmos (great flood) anxiously to be awaited.

The most prominent landmarks are now commonplace in the annals of intellectual and cultural history and can be touched on here in telegraphic Gashion:

(1) the Masonic "catastrophists" (Semyon Bobrov, Matvei Dmitriev-Mamonov, A. M. Kutuzov, Sergei Shirinsky-Shikhmatov) and other proto-Decembrists who forecast an end to the Russian Empire either by flood or by fire, ${ }^{86}$ and who set down a tradition to be reworked by Pushkin, Vladimir Pecherin, Vladimir Odoevsky, Mikhail Dmitriev, and others;

(2) the preaching of St. Seraphim (1759-1833) about another order of time beyond this world and his prediction that the visit of a tsar to a nunnery would initiate a period of great upheaval and carnage; ${ }^{87}$

(3) the heated debate over the "old" and "new" styles in Russian literature carried on by the Shishkovites and Arzamasians in the early years of the century;

(4) the broad interest in history spurred by many things: the defeat of $\mathrm{Na}$ poleon in 1812, the monumental work of Karamzin that followed, the sharp disagreements in print between Pushkin and Polevoy over the authority of the great historiographer in the post-Decembrist Uprising years, the spate of historical studies that appeared in the 1830 and that derived authority either from the idealism of Hegel and Schelling (Polevoy, Ivan Kireevsky, Pogodin) or from the skepticism of Niebuhr and Von Ranke (Kachenovsky), the emergence into prominence of the historical novels of Bulgarin, Lazhechnikov, Zagoskin, and, in general, the dogged search for a legitimate national identity promoted during the reign of Nicholas I (ruled 1825-55);

85 The title was to reappear as one of Lenin's most important reinterpretations of Marxist doctrine.

86 For the poetic treatment of the great flood (kataklysmos) and great fire (ekpyrosis) see, e.g.,
Bobrov's "The Fate of the Ancient World" (1789?) and DmitrievMamonov's "Fire” (1811?).

87 The visit would turn out to be made by Nicholas II in July 1903 and was seen to usher in the two revolutions. See Katerina
Clark and Michael Holquist, Mikhail Bakhtin (Cambridge, Mass.: Harvard University Press, 1984) 133-34, 372. 
(5) Chaadaev's famous critique, from the viewpoint of conservative French Catholic philosophy (de Bonald, de Maistre), of Russia's past (or absence thereof: "Isolated from the world, we have given nothing to the world; we have taken nothing from the world; we have not added a single idea to the mass of human ideas; we have contributed nothing to the progress of the human spirit"88), his premonition that some great turning point was at hand and that the establishment of the Kingdom of Heaven upon earth was imminent, and his radical volteface in Apologie d'un fou (1836), when the lack of an historical past is suddenly transformed into the promise of a future ("the future is ours"89);

(6) the search by the Slavophiles (chiefly Ivan Kireevsky, Alexei Khomyakov, and Konstantin Aksakov) for an ideal past in the concepts of sobornost' (the spirit of "free unity") and obshchina (the peasant commune), their desire to project that past into the future as the telos of Russian history, and their radical rejection of the Catholic and Protestant West - the one's "unity without freedom" (i.e., socialism) and the other's "freedom without unity" (i.e., the "egoism" of Max Stirner);

68. (7) Belinsky's provocative mot, echoing Chaadaev’s earlier historical claims, that "we have no literature";90

(8) Herzen's nagging fear of revolution ("This lava, these barbarians, this new world, these Nazarenes who are coming to put an end to the impotent and the decrepit... they are closer than you think"91), his skepticism about apocalypse and historical destiny ("history is all improvisation, all will, all extempore"92), his disenchantment with 1848, and yet his hope, during the period of "Russian Socialism," that his country - especially the Eastern frontier of Siberia - in its "newness" and "openness," could save the world from the corruption and philistinism of the European bourgeoisie;

(9) Bakunin's translation of Left Hegelianism into the joy of destruction (recall his notorious "Die Lust der Zerstörung ist auch eine schaffende Lust” [The desire for destruction is also a creative desire]) and total negation of the past;

(10) Dostoevsky's neurotic hatred of Switzerland, his falling out with Turgenev over the subject of Germany versus Russia, his savage parodies of the "men of the sixties," his anxiety over the rising tide of anarchy, terrorism, and nechaevshchina, and his predictions, especially in sections of Diary of a Writer written in the 1870 , that the Antichrist was afoot and

88 Peter Chaadaev, Philosophical Letters, and Apology of a Madman, trans. and intro. Mary-Barbara Zeldin (Knoxville: University of Tennessee Press, 1969), 41.

89 Ibid., 175.
90 V.G. Belinskii, Polnoe sobranie sochinenii, 13 vols. (Moscow: Akademiia Nauk SSSR, 1953-59), 1:22.

91 A.l. Gertsen (Herzen), Sobranie sochinenii v tridtsati tomakh (Moscow: Akademiia Nauk SSSR, 1954-65), 6:58-59.

92 Ibid., 6:34-35. 
the End was near ("The Antichrist is coming to us! He is coming! And the end of the world is near - nearer than they think"93);

(11) Leontiev's conservative scorn for equality, progress and enlightenment, his rejection of drab and tasteless European dress and habits, his eerie sense of living at the edge of an abyss, his legendary desire to "freeze Russia lest she rot," and his conviction that "we suddenly, from the depths of our state bowels [gosudarstvennye nedra]... will give birth to the Antichrist" and "will end history, destroying humanity in a bloodbath of universal equality";94

(12) Fyodorov's utopian attempt, in The Philosophy of the Common Cause $(1906,1913)$, to render apocalyptic retribution "from beyond" unnecessary through a program of universal brotherhood, scientific discovery, and literal resurrection - molecule by molecule - of one's ancestors;

(13) Vladimir Solovyov's conviction near the end of his life that the twentieth century would be "an epoch of last great wars, civil disorders, and revolutions," that would reign, and that as a result of a universal intermixing of East and West there would emerge a "superman... a great thinker, writer, and public figure," whose activities on the stage of history would appear as a kind of photographic negative, or anti-image, of Jesus Christ.95

These are just a few of the moments that, taken together, gave our novelists the overwhelming sensation of apocalypse and Endzeit. I do not mean to suggest that there is a direct or simple correlation between these ideas themselves and the structure (as opposed to the themes per se) of the novels under discussion, but only that certain assumptions about the meaning of Russian history - it is meaningful because it is ending soon, and any ending, whether punitive or expiative, confers meaning can also be made about the meaning of Russian history and individual biography as presented in narrative fiction. The time has come, however, to look more closely at what this means.

\section{Plot}

We have been speaking primarily of Russian history and the views of participants/spectators as to that history's alleged beginning and end. As we move to a discussion of fictional narrative and its presentation of a Russian apocalypse, it would be well to state several givens. First, as Arthur Danto has rigorously argued, there is a fundamental difference between historical crisis as viewed (or "lived") by a participant (say,

93 V.V. Timofeeva (Pochinkovskaia), "God raboty s znamenitym pisatelem," F.M. Dostoevskii v vospominaniakh sovremenikov, ed. V.V. Grigorenko et al (Moscow: Khud. lit., 1964), 2:170.
94 Konstantin Leon'tev, “Nad mogiloi Pazukhina," Sobranie sochineniia (Moscow: Izd. V.M. Sablina, 1912-13), 7:425.

95 Vladimir Solov'ev, Tri razgovora (New York: Chekhov, 1954), 193, 199.
69.

Chapter 2 
Avvakum) and that same crisis as viewed by the historian (say, Michael Cherniavsky) looking back and narrating it. ${ }^{96}$ The participant projects an ending, but the historian knows that that is how things turned out; the participant is still "inside" (hi)story, but the historian is by definition "outside" it, located temporally and spatially at that much invoked "meta-" level whence he or she can presumably, objectively and dispassionately, describe and therefore explain how the chronicle of events became history, how, in formalist terms, the "Fable" (fabula) became a "plot" (siuzhet), the "story" (histoire) a "discourse" (discours). ${ }^{97}$

Thus it is the historian's special role to generate, in Danto's terminology, "narrative predicates" - those statements which, when applied to objects, "do so only on the assumption that a future event occurs," and which are seen as "retrospectively false... if the future required by the meaning- rules of these predicates fails to materialize."98 Such narrative predicates make a special claim on the future, but it is a future only from the viewpoint of the participant. From the viewpoint of the historian it is already past: e.g., “Lenin's arrival at the Finland Station would [a modal the participant might have hoped for but could not know for certain] 70. unify the revolutionary movement and contribute to the collapse of the Provisional Government." On the other hand, while the historian can narrate the past, he or she cannot narrate the future; the very closedness of the past (the historian is located outside it) implies that the future is open and that, in this new context, the historian must trade the role of narrator for that of participant/spectator (he or she is inside and part of that which is still unfolding). "The very structure of narrative," concludes Danto, "entails the openness of the future, for only then can it in any way depend upon the present."99

So much has been written about the essential isomorphism of historical and fictional narratives ${ }^{100}$ that we tend to overlook the more basic difference between the narrative predicates characteristic of them. ${ }^{101}$ The historian, if consistent and not given to narrating what cannot, historically, be known, is limited to a description of the past, meaning that his or her "meta"viewpoint is only privileged vis-à-vis the participants of those already accomplished events and "turning points" at issue. To know the End from one's own viewpoint, from one's present, is to break the rules of a narrative predicate, and therefore to posit what for the historical narrative is an impossibility. "If the knowledge of the narrator [historian] were made available to the characters [participants, spectators], the structure of

96 Arthur Danto, Narration and Knowledge (New York: Columbia University Press, 1985), 342-63.

97 Seymour Chatman, Story and Discourse: Narrative Structure in Fiction and Film
(Ithaca, Cornell University Press, 1978), 19.

98 Danto, Narration and Knowledge, 349-50.

99 Ibid., 353.

100 Both historical and fictional narrators select out and "prefigure" their material, both tell "stories," even if one is, based primarily on "fact" and the other, with varying degrees of subterfuge, embraces its fictionality, etc. A fine distillation of the argument is found in 
narration would be destroyed." ${ }^{102}$ Danto is assuming, as indeed he must, that there is no higher viewpoint outside of and enclosing the historian's future which can be known and narrated as history. Yet this very stricture, essential to the integrity of historical narration, does not necessarily bind the unfolding of fictional narrative. Perhaps the most fundamental, ahistorical argument advanced by the "apocalyptic fictions" we will be examining is that narrators, like historians, do stand in a position of "metacognitive" superiority to their characters, but these characters can, if sensitive to the signs/symbols in these stories, know ("intuit") what their narrators know. This is not of course historical knowledge as Danto would define it, but to the characters (and to their narrators and authors) it is knowledge (one would probably have to call it "mystical" or "revelatory") nonetheless. ${ }^{103}$

In other words, the protagonists of these novels, who in several cases write versions of their own stories, may be paradoxically characterized not only as "chroniclers" but, in a sense, as "historians" - they are given, by their narrator or author, a foreknowledge of the future from the present. Located on the inside, they are vouchsafed aperçus that could come only from the outside. And, strange to say, not only does this not destroy narrative, it makes it rich and mystifying. We are constantly presented with Escher-like optical illusions, with narrative hierarchies that, like staircases climbing upward and simultaneously back into themselves, are both circular and open. For just as in fiction a character can have knowledge that by rights should only belong to the narrator (the Master "knows" that the stranger at Patriarchs Ponds is the Devil),

Suzanne Gearhart, The Open Boundary of History and Fiction (Princeton, N]: Princeton University Press, 1984), 3-28, but see also Roland Barthes, "Historical Discourse," in Structuralism: A Reader, ed. and intro. Michael Lane (London: Jonathan Cape, 1970), 145-55; Leo Braudy, Narrative Form in History and Fiction (Princeton: Princeton University Press, 1970); W.B. Gallie, Philosophical and Historical Understanding (New York: Schocken Books, 1968); Lionel Gossman, "History and Literature," in The Writings of History: Literary Form and Historical Understanding, ed. Robert H. Canary and Henry Cozicki (Madison: University of Wisconsin Press, 1978), 3-39.; J. Hillis Miller, "Narrative and History," ELH 41(1974): 455-73.; and Hayden White, Metahistory: The Historical Imagination in Nineteenth-Century Europe (Baltimore: The John Hopkins University Press, 1973). Gearhart's book is useful for its non-flamboyant discussion of the contributions of many of the chief participants in this dialogue, including Louis Althusser, Roland Barthes, Arthur Danto, Paul de Man, Jacques Derrida, Michel Foucault, W.B. Gallie, Claude LéviStrauss, and Hayden White.

101 C. Bakhtin's position on the difference between novel and history as explained by $\mathrm{Mi}$ chael Holquist in Mikhail Bakhtin, The Dialogic Imagination, ed. Michael Holquist and trans. Caryl Emerson (Austin: University of Texas Press, 1981): "But histories differ from novels in that they insist on a homology between the sequence of their own telling, the form they impose to create a coherent explanation in the form of a narrative on the one hand, and the sequence of what they tell on the other. This templating of what is enunciated with the act of enunciation is a narrative consequence of the historian's professional desire to tell 'wie es eigentlich gewesen ist' ["how it really was"]. The novel, by contrast, dramatizes the gaps that always exist between what is told and the telling of it, constantly experimenting with social, discursive and narrative asymmetries (the formal tetralogy that led Henry James to call them 'fluid puddings'” (xxviii).

102 Danto, Narration and Knowledge, 356.

103 To "narrate the world" in this way is to do something 
so too can the narrator, circumscribed by the work's beginning and end, have knowledge that should only belong to the author. Such then is the epistemological Phrygian Cap coming between the narrative hierarchies of historiography and fiction writing. The novel can play with, indeed be obsessed by, the meaning of history, but it can also freely undermine the logic of the narrative predicate without which historiography is impossible.

At this point I would like to offer a rough typology of a sub-genre of the modern Russian novel which I call the "apocalyptic fiction.” Along the way I will also suggest why certain current assumptions about novelistic form in general and narrative in particular do not always account for the "structure" of these works, which routinely question their own limits as verbal art only to posit a non-verbal (or non-verbalizable) meaning lying beyond. This is to say, in the first place, that an apocalyptic fiction is not an apocalypse, but a modern equivalent of one, a kind of sacred text or version of the Book through which the character and the narrator and, by implication, the reader - all in their separate, self-enclosed realms - are made privy to a "secret wisdom" from another space-time. For our purposes the following characteristics might be selected out as determinative in apocalyptic fiction: (1) a canonical subtext that plays an important role both thematically and structurally in the parent text (in our case the Apocalypse of John); (2) a living tradition with which the work enters into dialogue and against which it asks to be read (i.e., the work is not an isolated phenomenon); (3) an apocalyptic "set" or predisposition to read current historical crisis through the prism of the Johannine structures and figures (here, the Revolution as eschatological turning point to be either anticipated or retrospectively evaluated);104 and (4) an apocalyptic plot whose “deep” or mythological structure in modern novelistic terms is a recapitulation of the essential movement of the Johannine text.

Rather than looking at these novels through the either/or optic of structuralism or poststructuralism - that is, they are either self-regulating, self- inscribing linguistic units whose "anatomies" can be classified and dissected with the appropriate narratological langue (Tomashevsky, Barthes, Todorov, etc.) or they are generic anarchists whose chief raison d'étre is to subvert convention and tradition and to exist in what Bakhtin would call a zone of maximum openness with reality - we will see them as verbal forms that are simultaneously aware of their openness and

very similar to what Karl Solger and Friedrich Schlegel discussed and Ludwig Tieck, E.T.A. Hoffmann, and Heinrich Heine practiced under the rubric of "Romantic Irony." The romantic ironist, however, sees the character as the author's plaything, just as a human being is a puppet held up by a mocking deity's strings. To put it another way, the boundaryline between story and teller, narrative and narrator, is to be crossed only by "the fully- conscious artist whose art is the ironical presentation of the ironic position of the fully-conscious artist" (D.C. Muecke, Irony [London: Methuen, 1970], 20). Yet for these Russian writers and the tradition they were creating, 
closedness, and of the boundary between Wahrheit and Dichtung. As Frank Kermode has aptly remarked, these are the fragile "fictions of concord," the "plots of, or against, the world and time" that, neither pure reality nor pure myth, fully acknowledge the modern world's skepticism about holistic pattern and yet somehow are able to provide form enough to make sense of our lives. ${ }^{105}$

Let us now examine more closely the various elements of an apocalyptic fiction. To begin with, each of the novels in question alludes significantly to the Johannine text. These allusions are not merely thematic overlay, that is, their function is not limited to drawing the reader's attention to the fate of individual Russian heroes and Russian history caught at "biblical" turning-points or crises. Rather, we are invited to view the mythic "zone" of novelistic space (i.e., the themes, figures, and passages taken from Revelation) and the realistic "zone" of novelistic space (i.e., the openness and contingency of contemporary life and history) as being in profound dialogic interaction. It is not simply that the mythic zone subsumes and determines the realistic zone in a straightforward and simplistic allegory or that the realistic zone upstages and undermines the authority of the mythic zone in an irreverent parody, but that genuine meaning - what it really signifies to experience apocalypse and revelation in our time - must be sought in a full-scale and honest confrontation between the two.

Myshkin cannot be understood only - if at all - as the triumphant Christ of the Second Coming; nor can the manifest weaknesses of the Master or Yury Zhivago be explained away by calling them Christ figures; nor can we disentangle Petersburg's plot (in both senses of the word) by acknowledging the very real parallels planted there between the Bronze Horseman and the Antichrist. If the Christian myth does have the last word in these works, enclosing the aimless fux of chronos in a higher pattern, it is not an easily won victory. Rogozhin murders Nastasya Filippovna and Myshkin goes mad; Dudkin murders Lippanchenko and Nikolai Apollonovich almost blows up his father; the Master and Margarita die at the hands of the same Pilate who executed Yeshua when they drink the gift of his poison wine; Sasha Dvanov follows his fisherman father into Lake Mutevo and suicide; and Yury Zhivago dies a broken man, having lived the last years of his life in the house of a former servant, while Lara disappears into the camps and their orphan daughter is left to fend for herself. In each case, to read these heroes' and heroines' actions

the narrative hierarchy does not have to be in the shape of a closed and vicious circularity.

$\mathbf{1 0 4}$ Frank Kermode, "Apocalypse and the Modern," in Visions of Apocalypse: End or Rebirth? ed. Saul Friedlander et al. (New York: Holmes and Meier, 1985), 86.

105 Frank Kermode, The Sense of an Ending: Studies in the Theory of Fiction (New York: Oxford University Press, 1967), 59; “Apocalypse and Modern," 101.
73.

Chapter 2 
within history (or history as represented as narrative) is to read them as failure. Yet to conclude from this that the primary function of the apocalyptic subtext is parodic is, as most readers would readily affirm, to misinterpret something very basic. What Pasternak's title character says in high seriousness could be applied (with certain reservations) to the entire tradition we are investigating: "All great, genuine art resembles and continues the Revelation of St. John: it always meditates on death and thus always creates life."106

The question of tradition in these novels is potentially vexed for the simple reason that they can be said to form a conscious and coherent whole only from our position "on the outside," and then presumably only with a good deal of typological tampering. "Conscious" and "coherent" to which historian, which narrator? Julia Kristeva's concept of intertextualité ("the transposition of one or more systems of signs into another") is useful in this connection only if one is interested in isolating the boundaries of the novel as textual system and then demonstrating how, in time, those same boundaries are contaminated and "transposed." ${ }^{107}$ As even the casual reader can see, these five novels

74. do not form an "intertext" in the sense of master grid of biographical influence or literary provenance. The lines of influence are more tangled than that and in any case may go back further, often to Pushkin and Gogol, who were perceived in this tradition as mediators between Russia's "epic past" and the modern historical present. For example, Dostoevsky alludes prominently to Pushkin in The Idiot; Bely to Pushkin, Gogol, Dostoevsky and others in Petersburg; Platonov to Dostoevsky in Chevengur; Bulgakov to Pushkin, Gogol, and Dostoevsky in Master and Margarita; and Pasternak to Pushkin and the Symbolists in Doctor Zhivago. It is probably more accurate to say that these Russian novelists were reacting to the unique injunctions of their moment and to the sense of national crisis that had to be narrated and "domesticated" into meaningful structures for them personally. Their eccentric novelization of history brings to mind such celebrated Western apocalypticists as Robert Musil and D. H. Lawrence; the latter's view of historical epochs as a neo-Joachimist triad dominated by "Law," "Love," and the "Comforter" is uncannily similar to the ideas of Vladimir Solovyov and Merezhkovsky, just as his urge to translate an apocalyptic fervor into personal myth is rivaled only by that of Andrei Bely. Any quasi-Proppian analysis which advances a "master plot" at the expense of the "living" and changing

106 Boris Pasternak, Doctor ed. Leon S. Roudiez, trans.

Zhivago, trans. by Max Hayward and Manya Harari (New York:

Signet, 1958), 78.

107 Julia Kristeva, Desire

and Language: A Semiotic

Approach to Literature and Art,
Thomas Gora et al. (New York:

Columbia University Press,

1980), 15. 
aspects of the tradition cannot do justice to the existence in history, the historicity, of these forms.

What can be said without oversimplifying the case about the tradition of apocalyptic fiction on Russian soil is the following:

(1) the already mentioned eschatological orientation in cultural consciousness, which had its genesis in earlier centuries and which assumed an ever greater prominence with the rise of historiosophical/historiographical debate in the nineteenth century, was still experienced as real and vital by these writers and was incorporated into the structure of their fictions. ${ }^{108}$ All of these works provide compelling cases of how context, text, and subtext interact, since in them the authors borrow from given bodies of Russian messianic or eschatological thought and adapt them to their own purposes - for Dostoevsky, it was the Slavophiles; for Bely, Vladimir Solovyov; for Bulgakov, Pavel Florensky; for Platonov and Pasternak, Nikolai Fyodorov.

(2) In terms of richness and breadth of apocalyptic literature, there is nothing to compare in the Russian context with the Symbolist period and with the theme of "last things" in the many novels, stories, poems, essays and philosophical causeries of Vladimir Solovyov, Dmitry Merezhkovsky, Vasily Rozanov, Valery Briusov, Maximilian Voloshin, Alexei Remizov, Alexander Blok, Andrei Bely, and others. Indeed, it could be said without exaggeration that the "new" Soviet literature and the doctrine of Socialist Realism that it eventually engendered were logical - if often forced - extensions of this culture of "last things," and that the longawaited transitus from old to new, end to beginning, then to now, was not only historically determined, as many wished to believe, but also predetermined by this essentially Christian myth, ancient, potent, yet ever mutable. ${ }^{109}$ And

(3) taken together, these five works represent various responses of the novel form (from roughly 1860 to 1960) to the central apocalyptic event of modern Russian consciousness, which they either predict or "prophesy,"

108 As an aside one could mention the intelligentsia tradition of defining the perceived boundaries of epochal change with the help of certain root spatial and temporal metaphors: Radishchev's Journey from St. Petersburg to Moscow, Herzen's From the Other Shore and Endings and Beginnings, Turgenev's On the Eve, Chernyshevsky's "The Russian at the Rendezvous," Dobrolyubov's "When Shall the Real Day Come?" Bely's The Beginning of the Century and Between Two
Revolutions, Vyach. Ivanov's Furrows and Boundaries, etc.

109 This connection is especially clear in the "salvation programs," the plans to achieve secular, physical immortality, that surfaced either explicitly or implicitly in many Soviet works. Irene Masing-Delic, in her Abolishing Death: A Salvation Myth of Russian TwentiethCentury Literature, (Stanford: Stanford University Press, 1992), identifies a number of texts, including Khlebnikov's Ladomir, Ognyov's “Eurasia,” and Zabolotsky's Columns and The Triumph of Agriculture, where this theme of the literal overcoming of death is prominent. 
as in the cases of Dostoevsky and Bely, or look back on with the wisdom of disconfrming hindsight, as in the cases of Platonov, Bulgakov, and Pasternak.

It has long been maintained that as the idea of history as divinely inspired human activity with an imminent conclusion from without gave way to the idea of history as secular progress with an immanent conclusion here on earth the historical "plot" was constantly modified to include an ever wider and disparate reality. This plot, asserts Kermode, made its way not only into our histories but into our fictions - secular humanity's answer to the Book. In Natural Supernaturalism M.H. Abrams has further contributed to the discussion by demonstrating that the vast history of apocalyptic literature in the West reached its highwater mark during the period of the French Revolution: the millenarian enthusiasm and hopes for a new age found in the early works of the English and German romantics (especially Blake, Southey, Wordsworth, Coleridge, Schelling, Hölderlin, and Hegel) were severely tested in the wake of Jacobin terror. The end of history as they knew it - which should have come with the revolution but did not - was dealt with not by rejecting apocalypticism out of hand but by turning to an artistic re-visioning of reality which was able to accommodate the specter of disconfrmation. Thus, the central distinction between much of the earlier and later works of these poets and historians (from Wordsworth's Descriptive Sketches to his Prelude, from Coleridge's Religious Musings to his Rejection: An Ode, from Blake's Marriage of Heaven and Hell to his Jerusalem, etc.) involved a shift in emphasis from an "apocalypse of revolution," or a universal eschatology achieved through sudden and violent political means, to an "apocalypse of consciousness," 110 or a personal eschatology achieved through the agency of the poetic imagination. For the romantics of the post-revolutionary era the New Jerusalem was to be achieved, in Abrams' words, "not by changing the world but by changing the way we see the world." without ignoring important cultural differences, I would also propose that

110 C. M.H. Abrams' statement (Natural Supernaturalism [New York: Norton, 1971], 332) on the English and German romantics before the French Revolution and the Russian symbolists before the October Revolution: "[Their works] are written in the persona of the visionary poet-prophet, 'the Bard,' who present, past, and future sees; they incorporate the great political events of their age in suitable grandiose literary forms, especially the epic and 'the greater Ode'; they present a panoramic view of history in a cosmic setting, in which the agents are in part historical and in part allegorical or mythological and the overall design is apocalyptic; they envision a dark past, a violent present, and an immediately impending future which will justify the history of suffering man by its culmination in an absolute good; and they represent the French Revolution (or else a coming revolution which will improve on the French model) as the critical event which signals the emergence of a regenerate man who will inhabit a new world uniting features of a restored paradise and a recovered Golden Age."

111 Abrams: Natural Supernaturalism, 347 and "Apocalypse: Theme and Variations," in Apocalypse in English Renaissance Thought and Literature, ed. C.A. Patrides and Joseph Wittreich (Ithaca: Cornell University Press, 1984), 363. 
for Russian apocalypticists like Bulgakov and Pasternak, who wrote after 1917 and who had to make sense of the revolution's excesses and failings, this same shift to a personal eschatology and to an artistic, as opposed to a political, revisioning of reality is readily apparent.

Finally, as far as tradition is concerned, it can be argued that these works, and others like them, constitute a resilient set of counter-models to the Socialist Realist classic, and this may be one reason why they have become the tradition to be studied in the Western academy. Katerina Clark has described how certain elements of the Socialist Realist "master plot" can adapt to historical context and still remain cohesive (e.g., a hero's being historically "spontaneous" [stikhiinyi] or "conscious" [soznatel'nyi] can be characterized as positive or negative depending on the time and place of writing ${ }^{112}$ ). What the Socialist Realist classic is able to do with a remarkable economy of means is to "fabulize" a Marxist view of history by manipulating certain powerful and hallowed mythical categories: the Bolshevik hero, such as Gleb Chumalov, has been in touch with an epic past - he participated in 1917, performed legendary feats of heroism at the front, and knows people, like Shibis, who saw Lenin. And this contact with a sacred past confers the "right stuff" on Gleb; it allows him to confront and overcome a problem-ridden present (NEP) and make his way toward, but never actually to, the telos of communism. Likewise, Mother freely borrows the semantics of religious conversion to generate enthusiasm for the indisputable destiny of Gorky's Marxist "elect." Our primarily "Christian" authors, on the other hand, incorporate into their narratives a different view of history. Because meaning is not immanent or historically determined (that is, it does not come "from within"), it must be generated by comparing the disjunction between character and narrator, narrator and reader, and ultimately reader and God. What prevents dramatic irony in the Socialist Realist classic (the narrator does not play with character or reader because "enlightenment" is not relative and because "realism" implies a maximum proximity to history and a maximum distance from fiction), is precisely what makes meaning so richly polysemous in these relentlessly unrealistic works about the climax of Christian history. Here too we find characters "from beyond," as shall be suggested in more detail in a moment, but their function, in terms of the purpose or goal of history, is entirely different.

What are the essential elements of the "apocalyptic plot" and how do they relate to the works under discussion? First, each of these novels in a

112 Katerina Clark, The

Soviet Novel: History as Ritual (Chicago: University of Chicago

Press, 1981), 46-67. 
fundamental way is about the End. A number of contemporary critics have made studies of the device of closure in the modern novel, with the implication that, regardless of strategies for sealing off, or leaving open, a narrative, ${ }^{113}$ the entire structure of a work is inevitably "end-determined," that is, it is emplotted backwards, from, as it were, its "Finis" to its "Once upon a time..." Yet it is not enough to say that these works are simply enddetermined; both on the level of biography and on the grander level of Russian history, their narratives invoke the shadow of the biblical End. They are a search - and herein the spatial metaphor of the "path" or "road" (put') necessarily enters discussion - for the meaning of the Russian apocalypse. Their heroes' and heroines' stories are Russia's stories, and in much the same way as the reader of the Socialist Realist classic is urged to draw analogies between the fate of a member of the elect and the country at large (that is, there is an unmistakable homology between development of a Bolshevik hero and the shape of Marxist historiography), so too is the reader of these works drawn to see a connection between personal death and the end of national, even world history. Not for nothing does each of these novels conclude, and most begin, with a crucial death: Marie and 78. Nastasya Filippovna in The Idiot, Lippanchenko and Nikolai's parents in Petersburg, Sasha Dvanov's father and Sasha himself in Chevengur, Berlioz and the Master and Margarita in The Master and Margarita, and Yury's mother and father and Yury himself in Doctor Zhivago. As we proceed closer to 1917 (that is, from Dostoevsky to Bely), this parallelism between personal and national ends becomes more and more fraught with anxiety (and more and more formally complex). As suggested, however, those works written after 1917 (Chevengur, Master and Margarita, and Doctor Zhivago), when the connection between revelation and revolution has been disconfirmed and a qualitatively new era has not begun, still make comparisons between personal and national history, but use different strategies in order to avoid a literal prediction of the end of Russian history within time (e.g., Menippean satire/"mock apocalypse” in the case of The Master and Margarita, the secularization of the apocalyptic through Fyodorovian philosophy in the cases of Platonov and Pasternak).

To speak of the apocalyptic plot in narrative terms is also to make certain assumptions about the shape of Christian Heilsgeschichte. Despite their considerable variety, sophistication, and lack of orthodoxy (or Orthodoxy), these authors' views of history share a concern with those of the biblical prophets about the nature, compass, and narrative presentation of

113 E.g., the relation of end to beginning and middle may be "circular" or "parallel" or "incomplete" or "tangential," etc. See Marianna Torgovnik, Closure in the Novel (Princeton: Princeton University Press,
1981), 3-19, as well as Alan Friedman (Turn of the Novel [New York: Oxford University Press, 1966]), D.A. Miller (Narrative and Its Discontents: Problems of Closure in the Traditional Novel [Princeton: Princeton University
Press, 1981]), and David Richter (Fable's End [Chicago: University of Chicago Press, 1974]). 
the End - what would it look like from "here" or from "there"? how can its projected significance be read backwards to provide meaningful pattern in one's life now? what in this conclusion to history's plot is "fictitious" - the result of an insufficiently informed reading of the signs and what is "real" - the result of a truly higher understanding? If scholars of biblical texts such as Collins can speak of the "genre" of apocalypse in descriptive terms, then perhaps we can speak of a subset of the modern novel which takes the core elements of the biblical genre and adapts them to its own hybrid form. Among the assumptions about the narrative shape of history that enter into the biblical genre and that are relevant to our discussion are the following:

(1) History is determined by God's plot, but the individual is free to choose between positive and negative fields of action within that plot. In narratological terms, this means that characters are limited both as "actants" once they act and as verbal constructs once their action is described, but that they can free themselves from this epistemological prison and, as it were, unwrite their biographies once they know what the narrator/author does. ${ }^{114}$

(2) The latter, tumultuous stage of history which these modern novelists as "prophets" are describing follows the same triadic pattern of crisis-judgment-vindication found in Revelation and other canonical apocalypses. However, whereas the initial stages of crisis and judgment are usually self-evident, the final stage of vindication may not be, and depends on whether a higher authorial viewpoint of all-embracing unity and resolution - the novelistic equivalent of the biblical marriage of the Lamb and the Bride - can be posited from "within" the text.

(3) History is a totality, and its movement from beginning to end is also a return - from a paradise of innocence (the Garden of Eden) to a paradise earned through suffering (the New Jerusalem). ${ }^{115}$ In each of these novels the period of innocence or grace is "not of this world" and is experienced as a separate, enclosed epic past which took place prior to the principal action and which preceded the hero's and/or heroine's "fall into" history: Myshkin’s "Fairy tale” romance with Marie in Switzerland and Nastasya Filippovna's idyllic life at Otradnoe before the seduction by Totsky; Nikolai Apollonovich's dashing presence as an Ivan Tsarevich before his attempted rape of Sophia Petrovna; the Kitezh-like realm that Sasha's father goes to look for in Lake Mutevo and that, as the symbol of what separates parent from child, haunts and simultaneously moves Sasha forward in

114 A compelling example of this situation is presented in the mock apocalyptic ending to Nabokov's Invitation to a Beheading.

115 This movement, by the way, which is both a progression and a return, evokes the image of the romantic spiral, an image alluded to either explicitly or implicitly in several of the works under discussion and serving in them as an important structural principle. For more on the romantic spiral, see Abrams, Natural Supernaturalism, 183-87. 
his search for the Bolshevik City of the Sun; the Master's and Margarita's life with their novel and the lottery money before the work is finished and “crucified” by the literary establishment; Yura's adolescent notions about sex before he sees the frightening galvanism joining Komarovsky and Lara, and Lara's own virginal symmetry and beauty before these are shattered by the lawyer's "Roman" ethic. This paradise lost is then projected into the future, beyond the present crisis (and its boundaries as "text"), as the telos of personal and national history; if it is to be recaptured at all, it is only at the end, through suffering and death (compare, for example, the final resting place of the Master and Margarita outside history and the salvational status of the late Yury Zhivago's poetry). And

(4) an understanding of history, which all apocalypses profess to provide, is possible only by looking for signs - in artistic terms, symbols - of God's will in the otherwise baffling "text" of current events. Such "revelations" normally involve a conflation of narrative's mythical and realistic "zones": the buffoon Lebedev reading a central passage from Revelation to a brooding Nastasya Filippovna; the half-literate Styopka regaling the alcoholic Dudkin with popular versions of the Second Coming. Too marked

80. to be dismissed as parody, they might better be seen as those charged moments when another, authoritative voice from beyond intrudes into the text to speak of the End.

Another salient element of the apocalyptic plot is the messenger from a different temporality and spatiality who announces/reveals to the characters of this world that the end is at hand. To recall the basic terms of Collins' definition: “'Apocalypse' is a genre of revelatory literature with a narrative framework, in which a revelation is mediated by an otherworldly being to a human recipient, disclosing a transcendent reality which is both temporal, insofar as it envisages eschatological salvation, and spatial, insofar as it involves another, supernatural world." In the Johannine text itself, this messenger is the angel of God who provides the prophet with his vision and who takes his place "betwixt-and-between" the heavenly and earthly realms. The fact that the angel appears from somewhere outside history to a member of humanity trapped within history (and mortality) is the very essence of the revelation (apokalypsis). These novels also provide such a mediating figure, although often thinly disguised in what remains of a "realistic" tradition. Logically enough, his appearance in the lives of other characters usually raises questions of his or their sanity.

116 Bakhtin, on the other hand, would undoubtedly argue that the notion of human dialogue outside of time is literally inconceivable, a contradictio in adjecto. To speak of a Voice from outside time is, according to him, to release the listening hero (and reader) into a kind of "audiencelessness" (impossible) or "neotvetstvennost"

(unresponsiveness in various senses). Be this as it may, it is my contention that these novelists were attempting to project the narrative equivalent of just such an optical (or auditory) illusion. Their model for divine utterance is potentially non-binding with regard to the speaker's time and space (what has been said can be 
In The Idiot, this figure is the title character, that passionate advocate of beginnings (his offer of marriage at Nastasya Filippovna's birthday party) and ends (his thoughts on execution) who has come to fallen Petersburg and to life "in the middle" with his epileptic visions of an existence outside time; in Petersburg, it is the Bronze Horseman (and the Unicorn), who announces to the lesser characters that their end, and that of Russia, is imminent; in Chevengur-Sasha's father, who, having plunged into the lake, already knows the secret of death for which his son spends the entire novel searching; in Master and Margarita - Woland, who knows that there is a historical Jesus, a Satan, and an existence beyond death (which he brings Berlioz) and whose appearance sets off the race around the streets of Moscow that lands Ivan (a modern-day St. John?) in Rimsky's asylum; and in Doctor Zhivago, this figure is the mysterious Evgraf, the "angel of death," who, "as though falling from the skies," appears to Yury during his bout with typhus, helps to raise him, like Lazarus, from the dead, and at the same time encourages him to write poetry, the most tangible evidence of Zhivago's "talent for life." All these figures, then, come from or have access to a different temporality, and it is their role to enter history ("life in the middest") with messages, often cryptic or difficult to translate into the logic of everyday speech, about eschatological salvation ("life at the end").

What this also means, to subvert for a moment Bakhtin's logic with regard to novelistic discourse, is that this voice is not merely that of any other, whose status is equal and equally contingent, but that of the Other, whose status is transcendent and uniquely resonant. ${ }^{116}$ It is true that Myshkin's efforts to follow this voice and forego judgment only bring judgment with a vengeance; then again, to think this way is to judge him and the other protagonists within history, within the text. The voice that speaks to Myshkin during his epileptic aura, before his falling sickness, or to Homeless each Easter season when the injection, his symbolic crucifixion, releases him from his nightmare and puts him back in touch with a radiant and calm Master and Margarita, or to Yury at the moment of poetic inspiration when he becomes St. George and the wolves closing in on the house at Varykino become the dragons of history, is the voice from outside time. And while it does not ignore the reality principle, ${ }^{117}$ it does, contrary to Bakhtinian theory, suggest that human dialogue can be inscribed in divine monologue, that diachrony can unfold within a synchronous pattern.

unsaid) in precisely the way that human dialogue is not.

117 Again, it cannot be emphasized enough that all these characters are feckless in the eyes of history. 
No sketch of the apocalyptic plot would be complete without mention of its chief protagonist and antagonist, Christ and Antichrist. As suggested earlier, none of these novels is a transparent allegory promoting literalist notions of the End. Instead they are hybrid forms that often apply principles of irony and parody to subvert the received wisdom (whether it be Christian or Marxist) of the Orthodox view. In the final analysis, however, they are not simply subversive or ironic but committed to a vision of their own, which is often mystical or quasi-gnostical and, in the cases of Bely, Bulgakov, and Pasternak, tightly linked with the gift of artistic creation. ${ }^{118}$ The marked presence of Christ-like figures in nearly all of our novels - Myshkin ("Prince Christ"), the white Domino and Unicorn, the Master, Yury Zhivago - does not imply, at least in any obvious way, that these are versions of the triumphant Lord of the Parousia come to defeat the forces of the Beast and oversee the climax of human history.

The creators of these characters are too conscious of what history has wrought since Christ first made his appearance and supposedly conferred on time a unique meaning "from the end" to rely on the sort of "sudden relief

82. expedition from the sky"119 that appealed to the religious imagination of first and second century Christians. According to the typology set out by Theodore Ziolkowski in Fictional Transfigurations of Jesus, there is a danger in overinterpreting the "Christ-like" character in modern literature. If the features characterizing this hero do not add up to a consistently emplotted portrait, complete with the chief topoi, of the life of Jesus, then we are dealing with atmosphere and scattered allusion, but not with "fictional transfiguration." Thus, for instance, the majestic Pieter Peeperkorn in Mann's The Magic Mountain falls into the category of a modern transfiguration because his stay at the International Sanitorium Berghof has its climax in a parodic last supper and betrayal, while the character of Myshkin, for all its Christ-like qualities, does not. ${ }^{120}$ Still, even if some of these Russian novels do have characters who come closer to a "transfigured" Christ,"121 this may not be what is ultimately significant. Ziolkowski's definition turns out to be too limited for our purposes, particularly when the chief focus in these Russian novels is on death, judgment, and the end of history. We are not here dealing with a simple paradigm of Jesus redivivus or imitatio Christi (examples of which abound in the ecstatic tradition of socialist literature), but with the Christ-like figure who must live near the end of his own and (in Dostoevsky and Bely at

118 Platonov's work offers the clearest example of the collision of utopian and apocalypticist worldviews and, as the product of a proletarian dreamer deeply disenchanted by NEP, can rely on no higher belief in the transcendent value of language; it is thus unique in its pessimism and dark use of parody.

119 Rufus Jones, The Eternal Gospel (New York: Macmillan Co., 1938), 5.
120 Theodore Ziolkowski, Fictional Transfigurations of Jesus (Princeton: Princeton University Press, 1972), 3-6, 104-5.

121 E.g., not only does the Master share many of Yeshua's traits, but his burning 
least) his nation's history. None of these characters is the avenging Lamb of Revelation, the eerie field marshal on white charger come to scatter the forces of the unrighteous. Each must bear the judgment of history, his cross, and each must try to deal with what the end means for his time. Yet by now it should be obvious that if there is a way out, if history is to be transfigured, and if the humiliated Christ is to become victorious, it is through the Book.

Conversely, all those figures in these novels whose purpose it is to bring judgment are in essence fictional incarnations of the view that history, after Hegel and Marx, is its own highest court. ${ }^{122}$ They are punishers, avenging horsemen, not Christ-like but Antichrist-like figures. Among them we find Rogozhin, who is associated in the dream of Ippolit (the "unleasher of horses") with the beast of Revelation and with the great dumb mashina, the "iron horse" and its relentless ride, that crushes the most beautiful being in the world; the Bronze Horseman, who pours his molten essence into Dudkin, the second Evgeny, and bids him kill Lippanchenko; Kopyonkin, the quixotic knight of the revolution, who kills out of comradely feelings and whose Proletarian Strength, the Bolshevik Rosinante, tramples everything underfoot; Pilate, the Rider of the Golden Spear, who executes Yeshua against his wishes and who threatens Cayaphas with a flood of Arab horsemen; and Strelnikov, the executioner, who from his armored train strikes out against the enemies of the revolution.

\section{Steed}

Mention of the avenging horseman brings us to the final element of the apocalyptic plot - the means it has at its disposal for propelling itself forward, for moving, as fictional history, from beginning to middle to end. Since all of these novels, as apocalyptic templates, begin in a time

of the manuscript is obviously linked with the crucifixion of the historical Jesus.

122 “Hegel’s program was avowedly theological, was seen by him specifically as a regrounding of Christian revelation within the newly glimpsed limits of an intelligible human history. Thus, for instance, God brooding over the abyss becomes in Hegel Being in that moment of identity before its first self-estrangement through negation, and thus the Biblical creation of the universe becomes the process of self- estrangement through which Being splits off from itself into a realm of brute matter, and thus Apocalypse becomes the reconciliation of all contradiction and the abolition of all differences in an Absolute Spirit that, in a last negation of negation, resumes all things into itself... For Hegel, the notion of reality unfolding through contradictions and rising to ever-higher levels until Spirit at last becomes conscious of itself constituted no new Revelation but only (and here was the originality of Hegelian philosophy as he saw it) Revelation in its immanent form. History discovering its own meaning from the inside, humanity grasping itself not as the arbitrary creation of some absent sky-deity but the Spirit gradually becoming manifest to itself" (my emphasis; William Dowling, Jameson, Althusser, Marx: An Introduction to 'The Political Unconscious' [Ithaca: Cornell University Press, 1984], 44-45). 
of crisis, their starting points are not the biblical garden, but a time much closer to the Johannine climax. This proximity to catastrophe has important implications for the form their stories take. What will be suggested, following but not necessarily agreeing with Bakhtin, is that these novelists need some concrete way to visualize the rapid and ominous passage of time in space. To make a pun that Bely (if not my reader) would approve of, they need to find a way to translate theodicy, or a justification of God's plot in the face of recalcitrant reality, into “the odyssey," or the journey down history's road. Bakhtin's term for this artistic translation is the chronotope (lit: "time-space"), that is, the place(s) in the text where the novelist seeks to "materialize time in space," to work out an equation for the spatialization of human temporal desire within the terms permitted by one's historical context. For Bakhtin the chronotope is much more than a traditional generic rubric; it is, as Caryl Emerson has recently pointed out, a "category of consciousness," an "assumption about the workings of time and space" that every author must make in seeking to "totalize" his or her world. It always contains an element of evaluation that tethers it to the author's "here" and "now" 84. and, in this sense, it cannot be transcended. ${ }^{123}$ Perhaps the most obvious way - at least to the Western mind - for the novel as personal/national history to show movement is through the time-honored figure of the road, which in modern times of doubt, anxiety, and irony tends to be beset by all manner of thresholds, crossroads, borders, and spatio-temporal choices.

All of our novels are dominated by the haunting presence of a "threshold city," the end of history's road or the place where all paths converge as history prepares for eschatological change. Thus the two prerevolutionary novels are set in the doomed imperial capital of Petersburg and the three postrevolutionary novels are set either in the "fallen" Third Rome of Moscow or in the beclouded Civitas Solis of Chevengur. These cities are the precise focal points where, to apply Eliade's terminology, the "profane center" (e.g., the Whore of Babylon) and the "sacred center" (e.g., the New Jerusalem) meet, where the modern seer, straddling two different temporalities, catches glimpses of an otherworldly order in the midst of worldly chaos and revolution. Related to this phenomenon of mythical centering is what the structural anthropologist Edmund Leach, analyzing the binary elements of biblical narrative, defines as "liminality" - that is, the rules governing the limen, the place "betwixt-

123 Caryl Emerson, Boris Godunov: Transpositions of a Russian Theme (Bloomington: Indiana University Press, 1986), 5-6; see also Pavel N. Medvedev, The Formal Method in Literary Scholarship, trans. Albert J.
Wehrle (Baltimore: Johns Hopkins University Press, 1978), 129-30. 
and-between" the sacred and profane where the prophet experiences revelation:

Fined down to its essentials the argument [about thresholds] runs something like this. Uncertainty generates anxiety, so we avoid it if we can. The categories of language cut up the world into unambiguous blocks. The individual is either a man or a beast; either a child or an adult; either married or unmarried; either alive or dead. In relation to any building I am either inside or outside. But to move from one such clear state to its opposite entails passing through an ambiguous 'threshold,' a state of uncertainty where roles are confused and even reversed. This marginal position is regularly hedged by taboo.

This finding clearly has an important bearing on my general topic of the relevance of anthropology to biblical studies. For, after all, mediation between opposites is precisely what religious thinking is all about.

Thresholds, both physical and social, are a focus of taboo for the same reason that, in the Bible, inspired sacred persons, who converse face to face with God, or who, in themselves, have attributes which are partly those of mortal man and partly those of immortal God, almost always experience their inspiration in a 'betwixt and between' locality, described as 'in the wilderness,' which is neither fully in This World nor in The Other. ${ }^{124}$

The means that these Russian novelists find to place their heroes in a sacredtabooed zone “betwixt-and-between” are rather obvious: Myshkin’s idiocy and sexual ambivalence, Nikolai's androgynous status and Dudkin's alcoholic delirium, Sasha Dvanov's role as dreamy durak (as opposed to umnik), the Master's insanity, Yury's moments of illness and inspiration. More importantly, this state of social or psychological or artistic liminality is also associated with sites steeped in the Russian eschatological tradition. ${ }^{125} \mathrm{It}$ is, for example, at just such a sacred-profane site that Nastasya Filippovna must choose between the opposing versions of time represented by her prospective grooms, Myshkin and Rogozhin; or that Apollon Apollonovich, Nikolai Apollonovich, Dudkin, Lippanchenko, and Sophia Petrovna must learn what it means to be "doomed irrevocably" by the retributive horseman; or that the Chevengurians must labor to build a new life whose result is mass death; or that the Master and Margarita must experience first

124 Edmund Leach and D. Alan Aycock, Structuralist Interpretations of Biblical Myth (Cambridge: Cambridge University Press, 1983), 15-16.
125 The one exception being Chevengur, which follows a popular utopian model. 
crucifixion, then resurrection at the hands of their artistic child; or that Yury, on the eve of the revolution, must look for his Christmas star in the same candle in the window that Lara has asked Pasha Antipov to light as she sets out to shoot Komarovsky, the cause of her "fall."

What is equally intriguing, however, is that in these apocalyptic fictions, in these novels that progress by (fore)telling the end, the journey down history's road is accelerated and foreshortened, for we are near the end and about to reach it. Taking their cue from perhaps the best-known of all passages - Revelation 6:1-8, which depicts history's movement through four stages of horse and rider - these novelists develop elaborate symbolic networks around the image of the horse and its modern counterpart, the train ("the iron horse"). I would like to propose that the horse is a powerful visual tool in the hands of these verbal artists precisely because it is capable of telescoping in one economical image several traditions (the imperial, the folkloric, the religious) and because its inherent qualities (speed, beauty, elemental forces, comradeship, martial prowess) make it an ideal symbol for eschatological transit, for the tumultuous "ride" from one space-time to another. ${ }^{126}$

86. Imperially, the steed sets the ruler or the aristocratic knight (eques) apart from the common people. If the ancient Egyptians discerned something undignified about seating their ruler on horseback and thus preferred the chariot, the Greeks had no such scruples and in fact placed great emphasis on horsemanship. One aspect of Alexander's "greatness" that has come down to us was his prowess on horseback (it was said that his horse Bucephalus would accept no other rider), including his discomfiting of Darius from his chariot as depicted in a famous mosaic. The steed continued to acquire significance, becoming the attribute not simply of the eques, but, especially during the Roman Empire, of the emperor: witness the famous equestrian monument to Marcus Aurelius first erected on the Capitol as a symbol of his majesty and authority and later preserved during the Christian era only because

126 In my treatment of the imperial and folkloric equine traditions I have relied extensively on the following sources: D.N. Anuchin, “Sani, lad’ia i koni, kak prinadlezhnosti pokhoronnago obriada," Trudy Imperatorskogo Moskovskogo Arkheologicheskogo Obshchestva 14 (1890): 83-226; H.W. Janson, "The Equestrian Monument from Cangrande della Scala to Peter the Great," in Sixteen Studies (New York: Harry N. Abrams, 1974), 159-187; R. Lipets, Obrazy batyra i ego konia $v$ tiurko-mongol'skom epose
(Moscow: Nauka, 1984); George Levitine, "The Problem of Portraits, Late Allegory, and the Epic of the Bronze Horseman," in The Sculpture of Falconet, trans. Eda M. Levitine (Greenwich: New York Graphic Society, 1972), 51-60; Robert N.Watson, "Horsemanship in Shakespeare's Second Tetralogy," English Literary Renaissance 13 (1983): 274-300. See also A. Bartlett Giamatti, "Headlong Horsemen: An Essay in the Chivalric Epics of Pulci, Boiardo, and Ariosto," in Italian Literature: Roots and Branches, ed. Giose Ri- manelli and Kenneth John Atchity (New Haven: Yale University Press, 1976), 265-307; V.V. Ivanov, “Opyt istolkovaniia drevneindiiskikh ritual'nykh i mifologicheskikh terminov, obrazovannykh ot asva'kon'," in Problemy istorii iazykov i kul'tury narodov Indii (Moscow: Nauka, 1974); Gertrude Jobes, Dictionary of Mythology, Folklore, and Symbols (New York: Scarecrow, 1962), 789-91; L.P. Potapov, “Kon' $\checkmark$ verovaniiakh i epose narodov Saiano-Altaia," Fol'klor i etnografia (Leningrad: Nauka, 1977), 3:164-178; Beryl Rowland, 
it was rechristened "Constantine" (thus linking the notion of papacy to empire) and moved to the Lateran. After a hiatus of almost a millennium, the equestrian reemerged in the monuments of Donatello, Verrochio, Bologna, Mochi, and Bernini, and in the sketches of Leonardo. Particularly noteworthy about the Renaissance treatment is the fact that the concetto (the conceit or "spark" for the entire project) for the Reiterstandbild underwent gradual change: the horse and rider were slowly separated as part of an ensemble decorating a ducal tomb (e.g., that of Cangrande [1330] in Verona); the eques now no longer had to be a sovereign, but could be a mere condottiere, or captain of mercenary forces (e.g., Donatello's Gattamelata [1448-50] in Padua); and the steed became more animated and full of latent power to the point that, in Leonardo's sketches and especially in Bernini's sculpture of Constantine the Great (1654-70), it finally reared up on its hind legs. Bernini's equestrian monument occupies such a prominent place in this genealogy because it is located on the Scala Regia (the main landing of the Vatican), thereby forming the first image of papal authority that a visitor encounters, and because Constantine is presented at that moment of revelation - the "moving stasis" of the rearing horse captures this concetto perfectly - when he sees the cross in the sky and prepares himself to conquer in its name.

This first completed statue of the rearing horse became, significantly, the model for the Louis XIV equestrian monument at Versailles, which in turn would influence Falconet as he worked on the Bronze Horseman for Catherine. ${ }^{127}$ When Bernini's statue arrived in France, Louis' advisers urged that the rock support on which the statue rested be reconfigured in a representation of flames: at the time it was felt to be politically wiser to play down the imperial connotations and to recast the horseman in the role of a latter-day Marcus Curtius hurling himself into the abyss to save his earthquake-riven capital. Ironically, however, the earthquake was not to be forestalled, and in the wake of 1789 all royal equestrian statues in France save this one (which was conveniently located across the lake from the palace in a far corner of the park) were destroyed. And it is a double if not triple irony that Falconet, who supposedly despised Bernini, returned to the master's concetto (the rock rather than the flames) and that his statue of Peter the Great would have such an hypnotic effect on generations of the Russian intelligentsia faced with a similar specter of revolution. ${ }^{128}$

"The Horse and Rider figure in Chaucer's Works," University of Toronto Quarterly 35 (1965-66): 249-59; I.D. Sirotina, “Obraz konia $v$ russkom, altaiskom i iakutskom geroicheskom épose," Sibirskii fol'klor (Novosibirsk:
Novosibirskii gos. ped. institut, 1980), 41-61.

127 Bernini had virtually finished the statue of Louis before he (Bernini) died, but since it underwent various changes once it reached French hands (see below), it is the sculptor's terracotta bozzetto which most accurately preserves his intentions.

128 Janson, "The Equestrian Monument,”157-89. 
Bernini had originally wished to represent Louis on a rocky summit, "in full possession of that Glory which... has become synonymous with his name,"129 an idea which Falconet felt was justifiably transposable to the Russian context. Moreover, the snake being trampled underfoot was an allegory for defeated envy. But the Russian time-space in which this bronze "text" was erected quickly changed meaning. The tsar as modern Marcus Aurelius did not arguably mean much to the Russians, ${ }^{130}$ but the tsar as Christ-like St. George slaying the serpent (the pagan forces) of history did. Long before this, in the late sixteenth century, foreigners visiting the court of Ivan the Terrible's son Fyodor Ivanovich mentioned the existence of "a golden medal portraying St. George mounted on a horse," which was worn on the sleeve or hat of the recipient as a sign of "the highest honor that can be bestowed for any service whatsoever." ${ }^{131}$ In any event, the apocalyptic connotation of the horse and rider is very much in evidence on one of the extant fags of Ivan the Terrible, where we find Christ mounted on a white charger, surrounded by twentyseven angels on horseback, and escorted by the archangel Michael with his winged steed. The official order of St. George, the most popular of

88. all Russian military medals and the only tsarist decoration to survive (in altered form, of course) into Soviet times, was instituted in 1769, that is, some thirteen years before the unveiling of Falconet's statue on Petersburg's Senate Square. So while Peter had done his best to secularize the imperial iconography, it retained a religious referent after his death, even perhaps in Falconet's borrowed concetto. To subsequent generations the Moscow horseman could be seen as having moved-

129 Ibid., 166-67.

130 Wackaw Lednicki (Pushkin's "Bronze Horseman" [Berkeley, CA: University of California Press, 1955], 33-34) shows that Falconet, in his correspondence with Catherine and Diderot, openly opposed a recreation of the original Marcus Aurelius. He much preferred the idea of "Peter-thepacifist" and "Peter-the-legislator," with outstretched hand in a protective gesture (main protectrice). Nevertheless, in the court's efforts to legitimize Peter's role by tying the tsar to an older classical model, the connection with the Moscow horseman (St. George) was not avoided, especially in later generations (Blok, for example, was to compare specifically the rival horsemen: see Sergei Hackel, The Poet and the Revolution: Aleksandr Blok's "The
Twelve" [Oxford: Oxford University Press, 1975], 41). Moreover, the fact that Falconet's equestrian was rearing (as opposed to the original Marcus Aurelius on the Capitoline) gave the monument an energy and dynamic relation to its surrounding space which was of course not lost on Pushkin. Here the main issue is not what Falconet or Catherine intended, but what those coming after read into the statue and its present context as cultural myth. For an excellent (though not entirely objective) discussion of Pushkin's understanding of Falconet's work, see Lednicki, Pushkin's 'Bronze Horseman,' 25-42. Pushkin's view of the dynamic between rider and steed is given a structuralist interpretation in Alexander Zholkovsky, Themes and Texts: Toward a Poetics of Expressive- ness (Ithaca: Cornell University Press, 1984), 69-75.

131 These words belong to Giles Fletcher, an envoy of England's Queen Elizabeth I who visited Russia during the reign of Fyodor Ivanovich. See V. Durov, Russkie i sovetskie nagradnye medali (Moscow: Gos. Istoricheskii Muzei, 1977), 4. It is intriguing to note that on some of these medals there was simply a horseman, without the defeated dragon, or a unicorn. Some scholars attest that the dragon came later-that is, after the solitary horseman during the late fifteenth century, when Moscow was considering the significance of the fall of Constantinople and adopting as state emblem the two-headed eagle. For more on the history of the St. George medal and order on Russian soil, see A.B. Lakier, Russkaia 
against his will - to the city of Peter, St. George as having traded his lance for an arm pointed imperiously into Russia's future, and the serpent impaled by the lance as having become a snake trampled underfoot by the tsar's steed. ${ }^{132}$

Whether its rider was Christ or Antichrist, the majestic steed became the symbol of Russia rearing up into the space between the old and the new. If writers like Pushkin did not, for reasons of artistic temperament or historiosophical conviction, choose to make the connection between the monument and the apocalyptic end of Russian history (that connection would be established later), the reason was not, as we have seen, for any lack of eschatological tradition. ${ }^{133}$ Peter could be viewed in opposite ways: by enlighteners as a St. George stamping out ignorance and obscurantism so that Russia could leap into a better future; by sectarians as a man-god who had betrayed his role as tsar to become emperor and hence Antichrist. But regardless of one's a priori beliefs about the direction of Russian history, Peter on horseback came to signify a radical and total shift in time-space relations, the visual equivalent of his new calendar. That this tradition was later undermined by other equestrians, notably Paolo Trubetskoy's satiric monument to Alexander III in which Peter's spirited charger comes to resemble a hippopotamus, should not be seen as a serious challenge to, but as confirmation of, the remarkable potency of Falconet's work, which from Pushkin's poem on retained a mythical status, either positive or negative. The statue of a triumphant Lenin arriving at the Finland Station on his armored car (bronevik) is of course further evidence that even the Soviets felt

geral'dika, 2 vols. (St. Petersburg, 1855), 1:228-31, 290-91; and N.N. Speransov, Zemel'nye gerby Rossii (Moscow: Sovetskaia Rossiia, 1974), 25-26.

132 As I argue in "The Role of the Eques in Puškin's Bronze Horseman," the confrontation(s) between Peter and Evgeny in Pushkin's poem in fact revolves around their opposing roles as "pagan" versus "sacred" riders. When in the first confrontation, for example, Evgeny is frozen astride a stone lion (the heraldic symbol of Yury Dolgoruky, founder of Moscow), which in turn stands guard over one of Petersburg's new houses (instead of over the vetkhii domik, the "little old house" of Parasha, Evgeny's fiancée), it can be said that the hero's various attributes as "Moscow horseman" have been undercut and parodied by their transference to the seat of the Bronze Horseman, the new city's all-powerful kumir (idol) and cruel tutelary spirit. See David M. Bethea, "The Role of the Eques in Puškin's Bronze Horseman," in Puškin Today, ed. David M. Bethea (Bloomington: Indiana University Press, 1993), 99-118.

133 Pushkin, who was a highly irreverent Voltairian in his youth (the anti-religious element persists in his work only until about 1826) did not have what we would call today an apocalyptic "turn of mind." But he did take for granted that his readers and correspondents would have some knowledge of the last book of the Bible. There are in all five indisputable mentions of the apocalypse in Pushkin's literary works (including drafts) and letters: see A.S. Pushkin, Polnoe sobranie sochinenii, ed. V.D. Bonch-Bruevich et al., 17 vols. (Moscow: Akademiia Nauk SSSR, 1937-1959), 1:162-63, $3: 860,12: 174,13: 29,14: 121$. Most of these references are parodic, that is, Pushkin tended to use them in a comic rather than serious context, referring to himself during the first Boldino autumn (1830), for example, as sending regards from his "Patmos" (letter to M. P. Pogodin of November 1830 in 14:121). On another occasion, Pushkin includes an allusion to the Pale Horse of Revelation in a draft of the poem "Verses composed during a night of insomnia" (Stikhi, sochinennye noch'iu vo vremia bessonnitsy, wr. 1830), but then removes it, presumably because he did not want the elements of this mythological system to invade his art on a serious level. 
compelled to tap into a later, but transparently similar, version of the imperial equestrian.

Underlying our discussion of Falconet's and Pushkin's horsemen is another, larger issue. The Western tradition of equestrian statuary takes its roots from the notion of controlling, of "reining" in, a wild and passionate “body politic.” The centaur is half brute beast; Euripides' Hippolytus (like his namesake in Dostoevsky's The Idiot) lives up to his etymology as an "unleasher of horses"; and, perhaps most influential, Plato's Phaedrus presents the human soul in the allegorical guise of a chariot driven by reason and drawn by noble and ignoble horses - all these images have created a context in which countless writers depict royal heroes as both "reining" and "reigning."134 Among the ancient and modern authors who have adopted the Platonic metaphor or its correlate myth of the overproud Phaeton, one might mention Philo Judaeus, Plutarch, Augustine, Prudentius, Dante, Ariosto, Chaucer, Luther, Sidney, Spenser, Bunyan, Burton, Herbert, Jonson, and especially Shakespeare. ${ }^{135}$ Whether presenting the fatal error of Macbeth's vaulting ambition in an image of Phaeton, or equating the loss of Richard II's solar (regal) status to

90. Bolinbroke's mastery of his (Richard's) roan Barbary, or implying that Hal has come of age when he "uncolts" Falstaff and defeats his rival horseman of the "hotspur," Shakespeare returns incessantly to what he perceives as a necessary parallelism between ruling one's own passions and ruling those of the people. ${ }^{136}$ This, after all, is the notion of noble horsemanship from which, etymologically and culturally, the chivalric tradition grew. He who could control his own steed and unhorse his opponent was the ideal knight; and victory in combat was all the evidence needed to establish nobility and status. Hence in Western literature as in statuary it was essential to keep distinct the notions of horseman and horse, rider and ridden.

In Russia, however, where a tsar such as Peter was associated by a significant segment of the population with what was new and revolutionary and the people with what was old and orthodox, this Western formula could not be so easily transplanted. If Catherine and her German "enlighteners" could insist, on viewing Falconet's work as an expression of Peter's proud design to control the elements (and, by implication, the wild force of the people), then those of another generation could also see the tsar as that figure which, by turning Russia westward and upsetting the status quo, unleashed rather than reined in the passions of his

134 Watson, "Horsemanship," 275.

135 Watson, "Horsemanship," 275-79; see also Giamatti, "Headlong Horses"; and Rowland, "The Horse and Rider figure." Even Freud felt "spurred on" by the met- has the prerogative of determining the goal and of guiding the movements of his powerful mount towards it", Sigmund Freud, New Introductory Lectures on Psychoanalysis, trans. W. J. H. Sprott (New York: Norton, 1933; cited in Watson, “Horsemanship," 276). 
people. As Pushkin himself remarked in a plan (1830) for a work about the nobility: "Pierre I est tout à la fois Robespierre et Napoleon (la révolution incarnée)" - "Peter I is at one and the same time Robespierre and Napoleon (the revolution incarnate)." ${ }^{137}$ This very issue of Peter's unreining/unbridling became, among others, a focus in The Bronze Horseman for Pushkin's quiet polemics with his friend, the great Polish poet Adam Mickiewicz. ${ }^{138}$ The latter had recently, in the Digression of Part III of Forefather's Eve, criticized his "Muscovite friends" - singling out "the bard of the Russian people" - for their chauvinistic response to the Polish uprising of 1830-31. And one of his chief images for describing his (the oppressed Pole's) version of Russian history is that of Peter's steed racing out of control: "His charger's reins Tsar Peter has released; / He has been flying down the road, perchance, / And here the precipice checks his advance." ${ }^{339}$ Pushkin, with his genius for absorbing the most disparate viewpoints and making them his own, implies an answer to Mickiewicz in his introduction (Peter is magisterial and in control) at the same time that he makes "a crack... in the smooth surface of panegyrism" in the story that follows. ${ }^{140}$ The link between a natural and social unleashing is never stated in the poem, and yet this buried kinship is, to "gallop" ahead of ourselves a moment, one reason perhaps the reason - why a Western formula signifying imperial order became in time a Russian formula signifying apocalyptic chaos. Thus it will be our argument that Pushkin's Bronze Horseman, drawing as it does from sculptural, iconographic, and heraldic traditions which join Marcus Aurelius and St. George, Europe and Russia, not only marks the moment of maximal equipoise in the fictional depiction of Russian history but also is itself, with its unique stand-off of styles and thematics (eighteenth-century "panegyric"/nineteenth-century "realistic") ${ }^{141}$ and counterpointing of introduction and narrative sections, a perfect formal expression of that balance. ${ }^{142}$ Peter and his city are both splendid and cruel, and therein lies the enigma of Pushkin's masterpiece. ${ }^{143}$

136 Watson, "Horsemanship," 277ศf.

137 Pushkin, Polnoe sobranie sochinenii, 12:205; see also Lednicki, Pushkin's 'Bronze Horseman', 30-31.

138 Depending on context and audience, Pushkin's attitude toward his country could be both condemnatory and patriotic, just as his view of Peter's place in history was a complex mix of fascination and repugnance.

139 Translated and cited in Lednicki, Pushkin's 'Bronze Horseman', 29; my emphasis.
Lednicki (Pushkin's 'Bronze Horseman," 28-30) also suggests further that Mickiewicz's image of the unreined steed owes a debt to Pushkin's earlier poem "To Licinius," where the over-proud hero (and by implication Russia) is threatened with a fall because he can no longer control his chariot.

140 Lednicki, Pushkin's 'Bronze Horseman', 52.

$\mathbf{1 4 1}$ For the shift from panegyric (Kantemir, Trediakovsky, Sumarokov, Lomonosov, Derzhavin, etc.) to realistic (Gogol, Dostoevsky, etc.) treatment of
Peter and his city, see N. AntsySerov, Dusha Peterburga (Petersburg: Brokgauz-Efron, 1922).

142 Lednicki, Pushkin's

'Bronze Horseman,' 49-50.

143 Later commentators on the meaning of the city's mounted genius loci, including Dostoevsky, will ignore the capital's splendor - or see it in decline and foreground its cruel, tyrannical side. 
The question of the folkloric roots of the equine image is admittedly more vague and indeterminate, shrouded, as it were, in the mists of the popular memory/collective unconscious. Here its chief expression in the nineteenth-century literary tradition is found not in Pushkin but in Gogol, whose celebrated panegyric on Russia's destiny in the context of a troika ride had an immense impact on later generations of writers, including a strikingly apocalypticist reworking in Blok. Folklorically, the horse has always possessed distinct connotations. There is, to begin with, the most obvious - the bogatyrskii kon' (hero's steed) of epic poem and folktale, the brave, wise, and prophetic friend of Ilya or Dobrynya that leaps over mountains with the speed of an arrow and tramples the enemies of sacred Russia. ${ }^{144}$ Less well-known but equally potent source material for the popular imagination is the practice, widespread and ancient, of killing and burying a horse with its master. D. Anuchin, the eminent late nineteenth-century Russian anthropologist who examined primitive burial mounds (kurgany) in Slavic countries, came to the conclusion (echoed more recently by Eliade) that the horse is "pre-eminently the funerary animal." ${ }^{145}$ The horse is buried with its master not only to show respect 92. but also to give the deceased a way of traveling to the other world. This notion of conveyance is reinforced in the tradition of the sledge (sani), which carries the individual from an earthly home to the final resting place and which also is drawn by the horse. ${ }^{146}$ Similarly, the figure of a horse's head or "little horse" (konek) was placed on a Russian peasant's but to protect the family within from disaster and their flock from disease or infertility. ${ }^{147}$ If the konek was smashed by others or fell apart on its own, it meant that either death or some great misfortune was in store for the head of the household. Finally, in the peasant consciousness, and in its modern representation in the works of such poets as Esenin and Kliuev, the horse's head was the symbol of the popular cosmos (izbianyi kosmos), of the link between the sun ("there") and the earth ("here"), and of motion upward and outward into unknown regions. ${ }^{148}$ Therefore, the horse not only had important ties with the ritual of sacrifice and burial but also with the mythical put' (path) joining the little world of the peasant's but to the great world beyond. ${ }^{149}$

Beyond this, however, the horse has long had another, darker side in the popular consciousness - that associated with the "Scythian" marauder. It is at this point that the Russian tradition comes close to the generally positive or romanticized images of the Argentinian gaucho and the

144 Lipets, Obrazy, 124-249.

145 Anuchin, "Sani, lad'ia i koni," 83-226; Eliade, Myth of Eternal Return, 67.

146 The barque or boat (lad'ia) also suggests a "crossing- over" $-c$ c. the river Styx and the ferryman Charon of Greek mythology - but without the help of a horse.

147 P.A. Rovinskii, "Zemlia i volia," Chernogoriia v ee proshlom i nastoiashchem (St. Petersburg:
Tip. Imp. Akademii Nauk, 1897), 438.

148 Cf. Eliade's statement, in Shamanism: Archaic

Techniques of Ecstasy (Princeton: Princeton University Press, 1964), 470 , that the horse "facilitates the 
American cowboy, with the important difference that the latter horsemen were seen to "open up" (but not civilize) parts of their countries, while the Mongols imposed their "yoke" on a flourishing Kievan state. All of these roving men on horseback stood for something quite different from the chivalric tradition - volatile, unrestrained movement, freedom coupled with lawlessness, a nomadic lack of culture. As we see in the poems of such modern "Scythians" as Voloshin and Blok (in the latter especially the "chivalric" and "Mongol" notions of horse and rider often alternate and compete), the revolution conjured up past ghosts of mounted chaos sweeping into "European” Russia from the East. Ironically, as Blok maintained in the tortured logic of his essays, if its purpose was to bring down the corrupt edifice of European civilization, this "second coming" of Russia's Eastern origins was not without its cathartic truth. The "pagan" as opposed to "chivalric" horseman came to be an important prefiguring element in the intelligentsia's quest to understand its "Russianness." Russians, as Berdyaev said so often, needed a put' (path) of their own, regardless of where that path led; they were stranniki, wandering truthseekers, and they despised the "sedentary" (osedlyi) European. Borges' eulogy of the gaucho and of the latter's doomed attempt to conquer time and history by conquering space comes eerily close to certain "Scythian" passages in Zamyatin ${ }^{150}$ and others and indicates to what extent this popular myth of wanderlust is not unique or indigenous:

The figure of the man on the horse is, secretly, poignant. Under Attila, the "Scourge of God," under Genghis Khan, and under Tamerlane, the horseman tempestuously destroys and founds extensive empires, but all he destroys and founds is illusory. His work, like him, is ephemeral. From the farmer comes the word "culture" and from cities the word "civilization," but the horseman is a storm that fades away. ${ }^{151}$

To presume from the above that Gogol's Chichikov is a nineteenth-century Genghis Khan come to rape and pillage in a provincial backwater is,

trance, the ecstatic fight of the soul to forbidden regions."

149 Vasilii Bazanov, Sergei Esenin i krest'ianskaia Rossiia (Leningrad: Sovetskii pisatel', 1982), 70-77.

150 "The essence of the spiritual revolutionary was captured by Zamjatin's description of the Scythian: 'Over the green steppe speeds alone a wild horseman with streaming hair - the Scythian. Where is he speeding? Nowhere. Why? For no reason. He speeds simply because he is a Scythian, because he has become one with the steed, because he is a centaur, and because freedom, solitariness, his steed, the wide steppe are most dear to him.' The galloping Scythian symbolized freedom, unending movement, and solitariness - freedom to reject the present in the name of the distant future, unending movement as a guarantee of man's progress in the face of universal philistinism; and solitariness because the spiritual revolutionary and heretic was always an isolated figure who stood apart from the masses" (A.M. Shane,
The Life and Works of Evgenij Zamjatin [Berkeley: University of California Press, 1968], 18). See also the description of the centaur, of one who "has become one with the steed," in We when D-503 looks down at the world beyond the Green Wall from within the spaceship Integral.

151 Jorge Luis Borges, "Stories of Horsemen," New Republic (19 May 1982): 8. 
prima facie, not a little far-fetched. He is cultured (albeit superficially), his background is urban, he has a passion for order - in short, all the terms in Borges' formula are reversed. Yet everything that Chichikov creates and destroys is illusory. And more important, it is when Chichikov disappears into the wide-open spaces at the end of part one that Gogol's narrator abandons himself to lyrical ruminations on the troika and Russia's destiny and we enter a strange and privileged narrative space in the text. ${ }^{152}$ Here the horse-drawn troika (the Russian chariot) symbolizes the shift from everyday time (the provincial town) to epic time (the grand openness of Russia's future). We are meant to “cross over" with Chichikov (he is indeed a kind of mock-epic Charon) and rise above this world (he is also, at a higher level, a kind of Elijah). At the same time, Gogol's imperatives exhort us to enter into the sheer nervous excitement of the ride, the combination of pleasure and fear that the passenger feels as the troika and Russia hurtle into the future. Thus, along with Pushkin's poetic treatment of Falconet's statue, Gogol's folk-inspired apotheosis of the troika becomes another potent image of eschatological change to be adopted and reworked by later writers.

94. It is, to be sure, a risky enterprise to extrapolate a shape for Russian cultural history from scattered examples of the equine motif. The term "Trojan horse" means something quite different to us than it did to the Greeks, just as the horse that brought death to Prince Oleg in the Primary Chronicle is not - because of the context in which it is presented - the horse of Pushkin's adaptation. I would like to propose, however, that many nineteenth-century Russian writers combined myth and realism in their use of the horse and that this intentional modal confusion suggests that the abovementioned traditions were very much alive. We have already discussed Pushkin and Gogol, and, while space does not permit further treatment of them here, there are other examples in their work that lend credibility to our assumptions. ${ }^{153}$ To turn our attention elsewhere, Chatsky, the famous hero of Griboedov's Woe from Wit (1833), does not merely ask

152 For more on the poetics of space in Gogol, see lu. Lotman, "Problema khudozhestvennogo prostranstva v proze Gogolia," Uchenye zapiski Tartuskogo gosudarstvennogo universiteta 209 (1968): 5-50.

153 In Pushkin one could cite, for example, his poetic reworking of the legend of the prophetic Oleg and his important lyric "The Devils." In the first work it is predicted that the prince will die because of his steed, so Oleg cautiously remains apart from the horse until after the latter is dead.
The prophecy comes true, however, being his own troubled feelings and the connotation of equineinspired doom is realized when Oleg, come to visit the remains of his faithful friend, is fatally bitten by a snake lying in wait in the horse's skull. "The Devils" describes how the speaker's sleigh is caught in a snowstorm and how the horses, frightened by the eerie atmosphere, lose their way. The animals' wild movements and lack of a road/destination could symbolize several things at this juncture of Pushkin's career (1830), not the least of which about his forthcoming marriage. Gogol often used some form of horse-drawn conveyance as a way out of a difficult situation: Podkolyosin in Marriage makes a quick exit in a carriage rather than proceed to the altar, and the tormented Poprishchin in "The Diary of a Madman” imagines his escape from madness and the terrible conditions of the asylum in terms of a heavenly bound troika (another Elijah motif). The equine motif also appears at the end of the story "The Carriage" 
for his carriage at the end of the play; rather, he exclaims that "he is no more a rider" whose destination is Moscow and that he is going into the world to look for a more worthy residence. His departure is thus a direct appeal to the audience, a kind of "crossing-over" into their space-time and into their notion of Russia's historical put'. In other words, Griboedov uses, before Gogol, the formula of an equine exit from a fallen world.

In Lermontov's poetry and prose a spirited horse is repeatedly associated with a beautiful maiden: both horse and maiden may be destroyed (or "broken" or "run to death") by the speaker's or protagonist's passionate but fickle nature. One obvious example of this appears in A Hero of Our Time (1840), where Bela's death is inextricably linked first with Pechorin's cynical horse-trading and then with his efforts to "break" her, and where his loss of Vera finds an objective correlative in the death from exhaustion of his horse. A remarkably similar case can be found in Turgenev's "First Love" (1860), when Vladimir is shattered by the discovery that his father is having an affair with Zinaida, the object of his impossible adolescent infatuation. Indeed, in this instance passion becomes something much more than innocent horseplay; it is a galvanic force that binds "rider" to "mount" (the father is repeatedly referred to as a formidable horseman who curbs Zinaida much as he curbs his mare Electric) in a sadomasochistic duel until the moment when a blow delivered by his riding crop shows the unsuspecting boy the depth of their attraction. (It may well be that the sophisticated and well-read Turgenev was playing with a modern version of the Renaissance simile that linked the sex act with a man's domineering position "in the saddle.") And of course the most celebrated example of this cruel male horsemanship belongs to Tolstoy, whose elaborate description of the horse race in Anna Karenina (wr. 1873-77) makes an unmistakable connection between Vronsky "in the saddle" on the mare Frou-Frou, breaking her back with his careless riding, and Vronsky in relation to Anna, "crushing" her so much that she hurls herself beneath a train. ${ }^{154}$

and the fragment "Rome," but its demonic connotations are perhaps most evident at the end of "Nevsky Prospect": "When the entire city [Petersburg] is transformed into thunder and flash, myriads of carriages careen off bridges, postilions shout and jump off horses, and the devil himself lights the streetlamps for the sole purpose of showing everything in an unreal guise" (N.V. Gogol', Polnoe sobranie sochinenii, ed. N.L. Meshcheriakov et al., 14 vols. [Moscow-Leningrad: Akademiia Nauk SSSR, 1937-52], 3: 46).
As a folk symbol of Russia on the move, the troika was invoked regularly by members of Pushkin's pleiad: see, e.g., the spirited poem “Again the Troika” by Vyazemsky. Other writers (primarily poets) who developed the equine motif at this time, or earlier, include: Batiushkov ("The Song of Harold the Brave"), BestuzhevMarlinsky ("Saatyr"), Derzhavin ("The Chariot"), Küchelbecker (“Sviatopolk," “Rogday's Hounds”), Kozlov ("The Nocturnal Ride"), Krylov ("The Rider and the Steed"), Zhukovsky ("The Song of the Arab
[Sung] over the Grave of his Horse," "Svetlana," “Lenora,” "The Knight Rollon”).

154 For more on the connection between the steeplechase and the train ride in Anna Karenina, see my discussion in The Shape of Apocalypse. 
In Crime and Punishment (1866), Raskolnikov's terrifying dream of the mare beaten to death by a peasant is modeled on a similar description in Nekrasov's long poem About the Weather (wr. 1863-65). Nekrasov and Dostoevsky replace the powerful male steed (kon') of folklore with the bedraggled nag (kliacha) - this female horse symbolizes the silent (non-verbal), long-suffering Russia of Lizaveta, Sonya, and the narod. While "aristocratic" writers like Lermontov, Turgenev, and Tolstoy tend to conflate the curbing, breaking, or destroying of a high-strung mare with the "painful pleasure" of romantic love, Dostoevsky and Nekrasov, though in their own ways sadomasochistic, expand the mare image into a more "popular" horse, one not ridden by a privileged rider but compelled to draw a heavy burden in the workaday world. In fact, only with Dostoevsky does the horse (and its modern version the train) begin to assume a definite and indisputable apocalyptic resonance; Russian history has now entered a new and ominous stage, and for the first time personal and national ends are embodied in variations on the same image cluster. Finally, two notable equine allusions are provided by Leskov and Chekhov in the latter part of the nineteenth century. In Leskov's "Enchanted Pilgrim" (1873) Ivan Flyagin is a koneser (or "connoisseur" of the kon' - the pun is Leskov's), an expert tamer of horses, an extravagant drinker and male specimen of epic proportions, and a saintly and sinful strannik,; ${ }^{155}$ Chekhov's description of a popular world falling apart in an orgy of drunkenness and ignorance ("The Peasants" [1897]) is again symbolized by a horse, crazed by a fire and running out of control.

155 See Hugh McLean, Nikolai Leskov: the Man and His Art (Cambridge: Harvard University Press, 1977), 241-55.

156 An excellent

introduction to the mythic connotations of the horse and train in nineteenth- century Russian literature is found in Stephen L. Baehr, "The Troika and the Train: Dialogues Between Tradition and Technology in Nineteenth-Century Russian Literature," in J. D. Clayton, ed., Issues in Russian Literature Before 1917 (Columbus: Slavica, 1989), 85-106. Baehr's study provides numerous examples of how the horse and train were perceived as opposing concepts (old/new, traditional/modern, natural/mechanical, etc.) in both the popular and the educated imagination. Particularly pertinent to our survey are his comments about the various reworkings of the Bronze Horseman myth into railway terms: Vyazemsky's “Pyotr Alekseevich” (1867), a poem in which the tsar's mount becomes an "imperial tender" and his title "crowned engineer" (ventsenosnyi mashinist); or Nekrasov's “The Railroad” (1864), another poem about, among other things, the abused and forgotten workers who haunt the Moscow-Petersburg railroad as it is built by Count Pyotr Andreevich Kleinmichel (a surrogate for Nicholas I): the ghosts of these "little men" come to utter their "threatening exclamations" in much the same way that Evgeny, in Pushkin's poem, once uttered his demented challenge to the equestrian statue. For additional discussion on the theme of the railroad in nineteenth century Russian literature, see Wolfgang Gesemann, "Zur Rezeption der Eisenbahn durch die Russische Literatur," in Slavistische Studien zum VI Internationalen Slavistenkongress in Prag, 1968, ed. Erwin Koschmieder and Maximilian Braun (Munich, 1968), 349-71; and M.S. Al'tman, "Zheleznaia doroga v tvorchestve L.N. Tolstogo," Slavia 34 (1965): 251-59.

157 A more appropriate model of course, and one which actually surfaces in the text of The Idiot, is Don Quixote, a work which parodies and "novelizes" the by then dated model of the chivalric quest. It also plays an important role in Platonov's Chevengur, which focuses on the Bolshevik quest for a new and better world. See Chapter 3 
Dostoevsky's work suggests itself as a turning point in this tradition and a logical point of entrance because several of his major works, and The Idiot in particular, witness a joining of the notions of biblical end and the current direction of Russian history in the image cluster of the horse/ train. ${ }^{156}$ Personal tragedy expands into imminent national tragedy, and the metaphorical ride of Nastasya Filippovna, who is, on a mythical level, Russia "the fallen bride," is repeatedly presented as a composite of the third and fourth horses of Revelation $(6: 5-8)$ and of the railroad network that is poisoning the "waters of life" $(7: 17,8: 10,21: 6)$. Living in a later, more skeptical time, and fearing that the "religion" of rationality that the "men of the sixties" had imported from the West would lead to universal destruction, Dostoevsky reverses the terms of the chivalric epic - the genre in which a poet like Spenser could still equate England's progress toward a New Jerusalem of ideal governance with a knightly quest on horseback. ${ }^{157}$ Now the rider does not hold the reins but is driven by a diabolical machine toward the terminus of death. In such apocalyptically oriented writers as Dostoevsky and Leontiev, the train, with its domination over horse-drawn conveyance in the second half of the nineteenth century, gradually becomes the equivalent of the Petrine steed: it is once again the victory of the false "new" over the genuine "old," of godless European enlightenment over orthodox, organic Rus'.158 The train is so threatening as a symbol of doom (in the popular consciousness it was given not the neutral name poezd, but the marked one, mashinathe ultimate machine and handiwork of the Antichrist ${ }^{159}$ ) because it moves, like "atheistic" logic, along iron rails without any higher reason for being

("Chevengur: On the Road with the Bolshevik Utopia") of The Shape of Apocalypse, 145-85.

158 American writers and thinkers experienced some of the same reservations about the incursion of the machine world - especially the train - into pristine America, although, to be sure, there seems to have been more sheer fascination with the idea of progress and less of Russia's apocalyptically-tinged fears. See Leo Marx's classic The Machine in the Garden: Technology and the Pastoral Ideal in America (New York: Oxford University Press, 1964), 194- 98 , 209-16,227-65. Of all American writers, Hawthorne was probably the one most mesmerized by the mythological aura surrounding the appearance of the iron horse in his country: see, e.g., his chapter "The Flight of Two Owls" in The House of Seven Gables as well as his story "The Celestial Railway."

159 For example, in a "physiological sketch” (“Zheleznaia doroga mezhdu Peterburgom i Moskvoi" [The Railroad between Petersburg and Moscow]) that appeared in volume 54 of the journal The Contemporary (Sovremennik) for 1855 (43-71), the author ("S") repeatedly refers to the train as a mashina and dwells on the fears of his passengers toward the new form of transportation: "“Oh, tell me, please, isn't it dangerous to ride on the railroad?' asks a stout lady" on the very first page (43). A related, but popular (narodnyi) fear of the train is expressed by the character Fyoklushka in A. Ostrovsky's play The Storm and by one of Tolstoy's peasants in War and Peace. For more on the railroad motif and its "chronotopic" possibilities, see Chapter One ("The Idiot. Historicism Arrives at the Station") of The Shape of Apocalypse, 62-104. 
and because it reaches its destination, which in these apocalyptic fictions is often associated with death, with only a mechanical explanation of how it got there. Since the train is perceived as a self-enclosed ensemble of origin/destination, coach, rails, and telegraph, ${ }^{160}$ the passenger feels cut off from nature and the outside world and begins to experience the space-time of the journey in relative terms. ${ }^{161}$ Moreover, the shift from individual, aristocratic rider to collective, driven passengers (Dostoevsky was again one of the first to stress this melting-pot atmosphere of "manyvoicedness" in his description of a third class coach) makes the train a perfect "vehicle" for the expression of tumultuous social change. ${ }^{162}$ The train continues to be a powerful, and often apocalyptically colored symbol for both the popular and literary imagination well into the twentieth century: there is, for example, Esenin's famous race between flesh-andblood colt and iron horse in "Sorokoust"; Mandelstam's blending of the notions of music and iron, of a passing age rent by the screeching of train whistles, in his poem "Concert at the Station"163; Artyom Vesyoly's duel between bull and train in Russia Drenched in Blood; Andrey Platonov's and fellow proletarians' fervent belief that the train, as quintessential 98. machine, would be the liberating force in the new Soviet era; V. Ilenkov's metaphor of Soviet society as train and the party as the "driving axle" in the novel by the same name; ${ }^{164}$ and in the latter decades of the twentieth century there is Solzhenitsyn's description of the dismantling of "truetimbered" (kondovaia) Russia and the demise of its best representative in terms of a railway accident ("Matryona's Homestead”); and Venedikt Erofeev's tragicomic tale, punctuated with allusions to Revelation, of another doomed train-ride into alcoholic oblivion and death (From Moscow to the End of the Line [Moskva-Petushki]).

Thus, perhaps more than any other single ingredient of the apocalyptic plot it is the "chronotopic" picture of the horse/train that has had the most far-reaching implications for the shape of our various authors' thinking as inscribed in the movement of the different stories. Following Dostoevsky's lead, Bely, Platonov, Bulgakov, and Pasternak return, mutatis mutandis, to this image cluster as a way into the larger issue of how to conceptualize ("emplot") the movement of history - is it, for instance, linear, circular, or spiralic? It is presumably not fortuitous that, together with that of the train, the image of the horse has remained one of the most durable and rich in all Russian literature and culture: witness its prominent place (usually in some form of the chivalric, folkloric/Scythian,

160 The telegraph was added at a later point to aid in communication and prevent accidents.

161 See Wolfgang Schivelbusch, The Railway Journey: Trains and Travel in the $19^{\text {th }}$
Century, trans. Anselm Hollo (New York: Urizen Books, 1980). In general Schivelbusch is a rich source of information on how the nineteenth century European perception of space and time was radically changed by the presence of the train. He also provides numerous examples of the train in popular and elitist literature of the time.

162 In the "physiological sketch" referred to above there is a good deal made of the different 
or apocalyptic topos) in the works of Blok, Bely, Voloshin, and other Symbolists; in Esenin, Kliuev, and the peasant poets; in Shershenevich, Mariengof, Gruzinov, and the Russian Imagists. The list could go on to include Mandelstam, Tsvetaeva, Babel, Sholokhov, the émigré poet Vladimir Korvin-Piotrovsky - even Vs. Ivanov, Efm Dorosh, I. Gudov, and other converts to high Stalinist Socialist Realism. ${ }^{165}$ And one most remarkable recent example, Joseph Brodsky's poem about the black horse, has been shown by the Soviet scholar O.V. Simchenko to trace its ancestry to Anna Akhmatova and her recollection of 1936, the eve of the great purges: "Life [placed] us at the reins [lit. 'under the bridle' pod uzdy] of a Pegasus that [was] somehow reminiscent of the Pale Horse of Apocalypse or the Black Horse of the verses [i.e., Brodsky's] that [were] yet to be born." ${ }^{166}$ To be sure, not all of these writers employ the equine image within the explicit semantic field of "apocalypse," yet such a meaning may not be far off, especially if the given passage raises the issue of the shape and direction of Russian history and the endtime of the revolution. In this larger sense, one may go so far as to say that the Russian tradition of apocalyptic fiction is a unique metaphorical "unbridling" or "unreining" of those same relentless cultural categories (old/new, East/ West, pagan/orthodox) that had pursued the collective consciousness of the intelligentsia for centuries.

In the West, perhaps for the reasons advanced by Berdyaev and Lotman, or perhaps because the potent combination of national myth and fanatic millenarianism driving the human imagination down "history's road" came to be questioned sooner, few modern writers of the "large form" (especially after the Great War) enter into the living tradition of "apocalyptic fiction" as I have tried to define it. ${ }^{167}$ Only someone like D.H. Lawrence, whose novels are considered by many to go against the grain of Anglo-American modernism, rivals these Russian novelists in his persistent telescoping of personal, national, and biblical myths of the End (and Beginning). Let us then close our introductory remarks with Lawrence, who apparently

classes (first, second, and third) on the train and their respective attitudes, from boisterous to reserved, toward the journey. Dostoevsky was clearly laying claim to this recent phenomenon in his vivid presentation of the third class coach carrying Myshkin, Rogozhin, and Lebedev in the opening pages of The Idiot.

163 See discussion, e.g., in Omry Ronen, An Approach to Mandel'štam (Jerusalem: The Magnes Press, 1983), xvii-xx.

164 Katerina Clark, "Little Heroes and Big Deeds: Literature
Responds to the First Five-Year Plan," in Cultural Revolution in Russia, 1928-1931, ed. Sheila Fitzpatrick (Bloomington: Indiana University Press, 1978), 190-91.

165 Clark, Soviet Novel, 139,277 . For specific examples of the equine motif in the works of the symbolists, see Chapter Two ("Petersburg: The Apocalyptic Horseman, the Unicorn, and the Verticality of Narrative"), in The Shape of Apocalypse, 105-44..

166 Cited in O.V. Simchenko, "Tema pamiati v tvorchestve Anny Akhmatovoi," Izvestiia AN SSSR:
Seriia iazyka i literatury 44 (1985): 506.

167 This is not to say that the apocalyptic theme fades from Western literature (and culture) after World War I. On the contrary, it is quite evident in the works of modern drama - witness the plays of Girandoux, Ionesco, Beckett, Genet, and others (see Maurice Valency, The End of the World: An Introduction to Contemporary Drama [New York: Schocken, 1983], 419-37). And it is present in prose works from recent decades, such as Pynchon's Grav- 
had his own "Scythian" streak and who too felt compelled to seat his apocalyptic fervor "in the saddle"168:

Horses, always horses! How the horse dominated the mind of the early races, especially in the Mediterranean! You were a lord if you had a horse. Far back, far back in our dark souls the horse prances. He is a dominant symbol: he gives us lordship: he links us, the first palpable and throbbing link with the ruddyglowing Almighty of potence: he is the beginning even of our godhead in the flesh. And as a symbol he roams the dark underworld meadows of the soul. He stamps and threshes in the dark fields of your soul and mine. The sons of god who came down and knew the daughters of men and begot the great Titans, they had "the members of horses," says Enoch.

Within the last fifty years man has lost the horse. Now man is lost. Man is lost to life and power - an underling and a wastrel. While horses thrashed the streets of London, London lived...

But the rider on the white horse is crowned. He is the royal one, he is my very self and his horse is the whole mana of a man.

100.

PART I He is my very me, my sacred ego, called into a new cycle of action by the Lamb and riding forth to conquest, the conquest of the old self for the birth of the new self...

The true action of the myth, or ritual-imagery, has been all cut away. The rider on the white horse appears, then vanishes. But we know why he has appeared. And we know why he is paralleled at the end of the Apocalypse by the last rider on the white horse, who is the heavenly son of Man riding forth after the last and final conquest over the "kings." The son of man, even you or I, rides forth to the small conquest; but the Great Son of Man mounts his white horse after the last universal conquest, and leads on his hosts. ${ }^{169}$

ity's Rainbow. Nonetheless, the underlying faith in a Christian resolution to the biblical plot has become increasingly untenable, and what is now called "apocalyptic" is more and more the end as nothingness (an especially vivid theme in, say, Beckett). It is my argument that Russian writers such as Bulgakov and Pasternak fall more into a Christian tradition of Apocalyptik that is perhaps anachronistic by Western standards.

168 Compare, for example, the following passage from
Lawrence's Apocalypse and the passionate scene of Ursula and the horses at the conclusion of The Rainbow.

169 D.H. Lawrence, Apocalypse (New York: The Viking press, 1932), 125-28. 